\title{
Constitutional Constraints
}

\section{Citation}

Richard H. Fallon, Constitutional Constraints, 97 Calif. L. Rev. 975 (2009).

\section{Published Version}

http://www.californialawreview.org/assets/pdfs/97-4/09Aug_Fallon.pdf

\section{Permanent link}

http://nrs.harvard.edu/urn-3:HUL.InstRepos:11222676

\section{Terms of Use}

This article was downloaded from Harvard University's DASH repository, and is made available under the terms and conditions applicable to Open Access Policy Articles, as set forth at http:// nrs.harvard.edu/urn-3:HUL.InstRepos:dash.current.terms-of-use\#OAP

\section{Share Your Story}

The Harvard community has made this article openly available.

Please share how this access benefits you. Submit a story.

\section{Accessibility}




\title{
California Law Review
}

\begin{tabular}{lll}
\hline \hline Vol. 97 & August 2009 & No. 4 \\
\hline \hline
\end{tabular}

Copyright (C) 2009 by California Law Review, Inc.

\section{Constitutional Constraints}

\author{
Richard H. Fallon, Jr. $\dagger$
}

It seems natural to assume that a central function of the Constitution is to constrain officials. ${ }^{1}$ It seems almost equally natural, however, to question whether reality matches that assumption. The impetus for doubt comes from observing Supreme Court justices, judges, and other officials when they confront constitutional issues.

Skeptics have long questioned whether and to what extent the Constitution constrains Supreme Court justices. Charles Evans Hughes, who would later serve as chief justice of the United States, signaled the ground for concern when he remarked that "the Constitution is what the judges say it is."” Today as much as in Hughes's time, justices who are believed to hold substantively conservative views tend to reach judgments that political conservatives applaud. Correspondingly, justices who are perceived as liberal routinely come to conclusions that liberals favor. Occasionally a justice bemoans that he or she dislikes some result that the Constitution requires, ${ }^{3}$ but such protests rarely

Copyright (C) 2009 California Law Review, Inc. California Law Review, Inc. (CLR) is a California nonprofit corporation. CLR and the authors are solely responsible for the content of their publications.

$\dagger \quad$ Ralph S. Tyler, Jr. Professor of Law, Harvard Law School. I am grateful to Amanda Frost, Jack Goldsmith, David Law, Daryl Levinson, Martha Minow, Fred Schauer, Matthew Stephenson, and Adrian Vermeule for comments on previous drafts and to Elizabeth Barchas and Steven Horowitz for outstanding research assistance.

1. Cf. Stephen Holmes, Passions And Constraint 241 (1995) ("Liberal constitutions ... are designed ... to force officeholders ... to act against their own immediate interests in order to promote the general interest.”).

2. Charles Evans Hughes, Speech Before the Elmira Chamber of Commerce (May 3, 1907), in Addresses of Charles Evan Hughes, igo6-i9i6, at 185 (2d ed. 1916).

3. For example, Justice John Paul Stevens has described his own majority opinions in Kelo v. City of New London, 545 U.S. 469 (2005), and Gonzales v. Raich, 545 U.S. 1 (2005), as 
occur. Indeed, political scientists employing a so-called "attitudinal model" have achieved notable success in predicting the justices' votes based solely on whether newspaper editorials classified them as "liberal” or "conservative" at the time of their nominations. ${ }^{4}$

Questions about the Constitution's constraining effect on the executive branch may seem equally apt. In recent years, the Bush administration claimed nearly unlimited executive power to address perceived threats to national security, duly enacted legislation to the contrary notwithstanding. ${ }^{5}$ Often acting in secret and on the basis of legal opinions authored by hand-picked subordinates, high-ranking officials reportedly engaged in practices forbidden by previous understandings of the separation of powers and, according to one source, "sanctioned coerced confessions, extrajudicial detention, and other violations of individuals' liberties that had been prohibited since the country's founding." In the view of these officials, the Constitution's grant of executive power functions as a highly potent authorization to combat alleged threats unilaterally, but it imposes little or no constraint on the president, at least in the domain of national security.

One might also wonder how much, if at all, the Constitution constrains members of Congress. To take just one example, in the recurring debate about campaign finance reform, legislators who believe that restrictions would improve the political process invariably maintain that the Constitution permits their preferred initiatives. ${ }^{7}$ Conversely, opponents protest that in addition to embodying unwise policies, reform bills would violate the First Amendment. ${ }^{8}$

reaching "unwise" conclusions, but explained that "in each I was convinced that the law compelled a result that I would have opposed if I were a legislator.” Linda Greenhouse, Justice Weighs Desire v. Duty (Duty Prevails), N.Y. Times, Aug. 25, 2005, at A1 (quoting remarks delivered by Justice Stevens at a bar association meeting). See also N.Y. State Bd. of Elections v. López Torres, 128 S. Ct. 791, 801 (2008) (Stevens, J., concurring) (writing separately "to emphasize the distinction between constitutionality and wise policy”); Griswold v. Connecticut, 381 U.S. 479, 527 (1965) (Stewart, J., dissenting) (criticizing a law prohibiting the use of contraceptives as "uncommonly silly" and disagreeing with the prohibition on philosophical and social policy grounds, but refusing to declare the law unconstitutional).

4. See Jeffrey A. Segal \& Harold J. Spaeth, The Supreme Court and the Attitudinal Model 228 (1993) [hereinafter Segal \& Spaeth, Attitudinal Model]; see also Jeffrey A. Segal \& Albert D. Cover, Ideological Values and the Votes of U.S. Supreme Court Justices, 83 Am. Pol. ScI. Rev. 557 (1989).

5. See, e.g., Jack Goldsmith, The Terror Presidency: Law and Judgment Inside the Bush Administration 85-90 (2007); Jane Mayer, The Dark Side 45-46, 268, 328 (2008); Charlie Savage, Takeover: The Return of the Imperial Presidency and the Subversion of American Democracy (2007); John Yoo, War by Other Means: An Insider's Account OF THE WAR ON TERror 102-04, 113, 168-87 (2006); Jules Lobel, Conflicts Between the Commander in Chief and Congress: Concurrent Power over the Conduct of War, 69 OHIO ST. L. J. 391, 391-92 (2008).

6. MAYER, supra note 5, at 328.

7. See, e.g., Brief for Intervenor-Defendants, McConnell v. FEC, 540 U.S. 93 (2003) (No. 02-1674).

8. For example, Senator Mitch McConnell, who was a leading Senate opponent of campaign finance reform, swiftly became the named plaintiff in McConnell, the leading case 
When policy preferences align so regularly with judgments of constitutional permissibility, questions naturally arise about whether the Constitution genuinely constrains legislators’ policymaking.

Although issues involving constitutional constraints are both important and timely, the general topic of the existence, nature, and efficacy of constitutional constraints has received little systematic exploration by legal scholars. ${ }^{9}$ Most of the best work in American constitutional theory is normative, focused on questions of how Supreme Court justices ought to decide contested cases. ${ }^{10}$ Given their normative orientation, constitutional theorists typically assume that judges are motivated to do their constitutional duties, even if they are currently mistaken about the interpretive methodology that they ought to use. Such theorists pay little attention to non-normative constraints on judicial action. ${ }^{11}$

By contrast, political scientists concern themselves more frequently with constraints, especially as perceived by officials whom they assume to be rational maximizers of their personal, typically ideological, preferences. $^{12}$ Strategic actor models of official behavior are highly illuminating in identifying the challenges that frequently confront officials (including judges) who understand that the effects of actions that they might take-however motivated-will depend on the responses of others. But work that models public officials as strategic actors almost necessarily highlights the motivational force of ideology and self-interest. Such work seldom probes the ways in which legal norms may shape officials' goals and thereby constrain their behavior. ${ }^{13}$ In addition, theories that portray judges, in particular, as

challenging the Act's constitutionality in the Supreme Court.

9. An important recent exception to this generalization is RicHARD A. PosNer, How JUdGES THINK (2008), which includes chapters on both internal and external constraints on judicial decision making.

10. See, e.g., Barry Friedman, The Politics of Judicial Review, 84 Tex. L. REv. 257, 257 (2005) ("In the legal academy, scholarship about judicial review is predominantly normative. It is largely about how judges should decide cases and what posture they ought to take toward the work of other institutions.”) (footnotes omitted).

11. For explorations of the possible ways normative theorists might use positive constitutional theory, see Adrian Vermeule, Connecting Positive and Normative Legal Theory, 10 U. PA. J. Const. L. 387 (2008); Friedman, supra note 10.

12. Indeed, John Ferejohn, Positive Theory and the Internal View of Law, 10 U. PA. J. Const. L. 273, 280 (2008), treats as a necessary element of a "positive theory" that it include a description of "the institutional, physical, and fiscal constraints" of relevant actors, along with "the preferences of the agents, the sets of actions each can take... and a description of the outcomes that arise as a function of the actions taken by the agents." For some examples of political science scholarship viewing judges as rational maximizers operating subject to constraints, see Lee Epstein \& Jack Knight, The Choices Justices Make 9-10 (1998); McNollgast, Politics and the Courts: A Positive Theory of Judicial Doctrine and the Rule of Law, 68 S. CAL. L. ReV. 1631 (1995).

13. Cf. Robert D. Cooter, The Strategic Constitution 376 (2000) (acknowledging that from an economic perspective, "an internal obligation [is] a preference," but acknowledging that "[f]rom a psychological viewpoint ... respect for the law does not feel like a preference for 
constrained strategic decision-makers have often taken a backseat in the law reviews to "attitudinalist" literature ${ }^{14}$ that assumes Supreme Court justices are single-minded maximizers of their political preferences who face few, if any, constraints in voting to advance their ideologies. ${ }^{15}$ Political scientific studies that attempt to account for judges and justices being motivated by a sense of legal obligation, including scholarship from a "new institutionalist" school, ${ }^{16}$ have not yet attracted the attention in legal scholarship that they deserve.

If any field of legal study has paid close attention to the respective significances of normative and non-normative constraints, it is jurisprudence. In jurisprudence, the roles of threats, sanctions, and norms in constituting and sustaining legal regimes often lie at the center of inquiry. ${ }^{17}$ For the most part, however, jurisprudential scholarship tends to be general and abstract, focused

asparagus or waterskiing”); Ferejohn, supra note 12, at 275 (“[M]ore common forms of positive theory take preferences and constraints to be determined by factors external to the legal system.”).

14. For well-known statements of this "attitudinal model," see SEgAL \& SpAETH, Attitudinal Model, supra note 4; Jeffrey A. Segal \& Harold J. Spaeth, The Supreme Court and the Attitudinal Model Revisited (2002) [hereinafter Segal \& Spaeth, Attitudinal Model Revisited]; Harold J. Spaeth \& Jeffrey A. Segal, Majority Rule or Minority Will: Adherence to Precedent on the U.S. Supreme Court (1999) [hereinafter Spaeth \& Segal, Adherence to Precedent].

15. See Segal \& Spaeth, Attitudinal Model, supra note 4, at 360 (asserting that the influence of non-attitudinal factors appears to be “overwhelmingly insubstantial”). Although the attitudinal model has attracted increasing criticism, many of the most telling political scientific critiques - which identify constraints to which judges and justices must respond "strategically" (rather than always voting in straightforward accord with their ideologies)—share the attitudinalists' assumption that legal decision-makers experience no normative constraints arising from legal obligations to obey the Constitution. See, e.g., Lee Epstein et al., The Supreme Court as a Strategic National Policymaker, 50 EMORY L.J. 583, 592 (2001) (proposing a "strategic approach" that "starts off with” the attitudinalist premise that justices are "single-minded seekers of legal policy"' but assumes that they must behave strategically in order to advance their policy goals effectively).

16. A number of political scientists, especially those described as "new institutionalists," acknowledge and indeed emphasize the significance of felt normative obligations - many if not most of which arise from a sense of institutional role-as an important consideration motivating judicial decisions. See, e.g, Rogers M. Smith, Political Jurisprudence, the "New Institutionalism," and the Future of Public Law, 82 Am. PoL. ScI. Rev. 89 (1988); Howard Gillman, What's Law Got to Do with It? Judicial Behavioralists Test the "Legal Model" of Judicial Decision Making, 26 Law \& Soc. Inquiry 465, 486 (2001) (reviewing Spaeth \& Segal, Adherance to Precedent, supra note 14); Keith E. Whittington, Once More unto the Breach: PostBehavioralist Approaches to Judicial Politics, 25 Law \& Soc. Inquiry 601 (2000) (reviewing Supreme CourT Decision-Making: New Institutionalist Approaches (Cornell W. Clayton \& Howard Gillman eds., 1999) and The Supreme Court in American Politics: New Institutionalist InTERPRETATIONS (Howard Gillman \& Cornell Clayton eds., 1999)); see also Stefanie A. Lindquist \& David E. Klein, The Influence of Jurisprudential Considerations on Supreme Court Decisionmaking: A Study of Conflict Cases, 40 LAw \& Soc'Y REv. 135, 156 (2006) (concluding that an empirical study of the Supreme Court's cases involving issues that have divided the federal courts of appeals "strongly support[s] the view that judges and justices engage in sincere efforts to find solutions that are persuasive according to a commonly held set of criteria”). For introductions to new institutionalist scholarship, see, for example, Supreme Court Decision-Making, supra; The Supreme Court in American Politics, supra.

17. See H.L.A. Hart, The Concept of Law 18-99 (2d ed. 1994). 
on what H.L.A. Hart referred to as "the concept of law."18 Jurisprudential writers seldom turn their attention to distinctively constitutional constraints or to the institutional settings of particular officials in particular legal systems.

My principal goal in this Article is to open up the subject of constitutional constraints as a topic for inquiry in American constitutional theory. Specifically, I mean to frame-and then to make some initial progress toward answering - the questions whether, how, and to what extent the Constitution constrains official decision-makers.

In pursuing that inquiry, I begin in a loosely philosophical vein by critically examining, in Part I, the ideas of constitutional constraint and nonconstraint. Upon analysis, the thought that officials holding constitutionally constituted offices might be wholly unconstrained by the Constitution proves incoherent. To be a president or a member of Congress or a justice of the Supreme Court is to serve in an institution that is constituted and empowered by the Constitution and, as a result, necessarily constrained by it. ${ }^{19}$ As both a conceptual and a practical matter, the alternative to constrained presidents, congressmen, and justices is not unconstrained officials, but rather no presidents, congressmen, or justices at all. In short, to be an official in our constitutional regime is to be constrained by both the Constitution and the legal institutions that the Constitution establishes or supports. ${ }^{20}$ The most important question is not whether the Constitution constrains, but how.

To begin to answer that question, Part II develops a typology of constitutional constraints. In so doing, Part II adopts a conceptual approach suggested by The Federalist 51 , $^{21}$ which discusses the need to supplement defects in officials' norm-based commitments to do what they ought to do with constraints arising from checks imposed by others. ${ }^{22}$ The former I characterize as "normative constraints," and the latter as "external constraints." 23 In

18. See id. (emphasis added).

19. See Holmes, supra note 1 , at 163 (noting that the Constitution simultaneously constrains and empowers those holding offices that it helps create).

20. Although I refer separately here to "the Constitution and the legal institutions that the Constitution establishes or supports," I shall often use the term "the Constitution" in a capacious sense that subsumes or incorporates institutions - for example, courts and the President-that are established by or draw their legitimacy from that written text. As I shall explain in slightly more detail below, see infra notes 60-82 and accompanying text, because the written Constitution can constrain only insofar as it is accepted and put into practice, it is hard, if not impossible, to make sense of the idea that the Constitution is capable of "constraining" in the absence of institutions that reflect or even embody the written Constitution's acceptance.

21. The Federalist No. 5I (James Madison) (Clinton Rossiter ed., 1961).

22. See id. at 320-23.

23. I use the term "external constraints" more broadly than Madison did. Madison contrasted "internal" constraints, which were those established and enforced within the federal government, typically by one branch against another, with "external" constraints, which originated outside the federal government's tripartite structure. See id. at 320-23. As I explain more fully below, I use the term "external constraint" to embrace both of Madison's categories of the internal and the external. For my purposes, the pertinent contrast is between constraints rooted in norms 
elucidating the idea of normative constraints, Part II draws on jurisprudential scholarship, especially that which H.L.A. Hart produced and inspired, ${ }^{24}$ which emphasizes that foundational legal rules can be seen from either an "internal" or an "external" point of view. ${ }^{25}$ As portrayed by Hart, the internal point of view is that of someone who "accepts" legal rules, such as those embodied in the Constitution, as providing her with reasons for action. ${ }^{26}$ The external point of view, on the other hand, is that of someone who may not regard legal rules as normatively authoritative for her, but who wishes to understand the thinking of those who do, often to predict the consequences of noncompliance. ${ }^{27}$

Viewed from an internal perspective, the Constitution furnishes standards of legally required and forbidden conduct that guide at least some officials' judgments that they have obligations trumping or displacing what they otherwise might wish to do. Insofar as officials regard the Constitution from an internal point of view, they will be constrained by constitutional norms or be subject to normative constraints. ${ }^{28}$ In its logically primary usage, the notion of normative constraints refers to legal rules or norms that exist independently of the mind of any particular official. ${ }^{29}$ Although a legal system cannot exist without broadly shared agreement about how to differentiate law from nonlaw, ${ }^{30}$ individual officials can sometimes be mistaken about what the law permits or requires them to do. For example, a conscientious official might believe the Constitution authorizes the executive branch to employ brutal interrogation methods that the courts would rightly construe the Constitution to forbid. In other cases, officials may think they have constitutional duties, when in fact they do not. ${ }^{31}$

("normative constraints"), on the one hand, and those rooted in concerns about adverse consequences ("external constraints"), on the other.

24. HART, supra note 17.

25. See id. at 55-56, 86-89.

26. See id. at 11 (explaining that to accept a social rule is to treat the rule as a "reason and justification" for action); see also id. at 90 (explaining that a social rule can form the "basis for claims, demands, admissions, criticism, or punishment"). For lucid and sympathetic commentary on the Hartian idea of an internal point of view, see Scott J. Shapiro, What Is the Internal Point of View?, 75 FordHAM L. Rev. 1157 (2006).

27. See HART, supra note 17 , at 87.

28. See generally The Oxford Companion to Philosophy 626 (Ted Honderich ed., 1995) (characterizing a norm as an action-guiding or reason-giving precept or principle, deviation from which would provide a ground for reproach within an appropriate domain such as that of morals, law, or etiquette).

29. Cf. Dale Smith, Ronald Dworkin and the External Skeptic, 19 CAN. J.L. \& JURIS. 433, 433-34 (2006) (discussing "mind-independence" of norms).

30. See John R. Searle, The Construction of a Social Reality (1995) [hereinafter Searle, Construction].

31. In so asserting, I obviously assume that some constitutional questions have correct answers. The jurisprudential question of what makes a legal answer correct has occasioned the spilling of much ink, see, e.g., HART, supra note 17, and this is surely not the occasion for me to attempt to contribute to, or even to summarize, the relevant literature. I assume, however, that in the myriad of "easy" cases, most of which never get litigated because the Constitution's meaning and application are too obvious to trigger dispute-see infra notes 67-76 and accompanying 
In another usage, however, normative constitutional constraints take the form of constitutionally inspired experiences of obligation, for it is only as refracted through individual minds and consciences that legal norms can be motivationally efficacious. ${ }^{32}$ As this usage may suggest, psychological apprehensions of constitutional obligation can exist even in cases of reasonable disagreement about what the Constitution requires ${ }^{33}$ and, perhaps more jarringly, even when an official is mistaken about the Constitution's dictates. ${ }^{34}$

At this preliminary stage, one last point about normative constraints should be introduced. In speaking of normative constraints, I assume that at least some officials are sometimes motivated to act out of a sense of constitutional obligation, even when their rational self-interest or political values would otherwise lead them to act differently. Norm-skeptics, who believe that people are irreducibly self-interested, of course reject this assumption. ${ }^{35}$ In their eyes, every example adduced to show that someone acted

text—all of the leading theories will converge in their acknowledgment of what the correct answer is, even if they provide divergent explanations as to why. In "hard" cases in which legally knowledgeable parties reasonably disagree about what the Constitution requires, I believe that a tacitly recognized rule of constitutional practice, grounded in acceptance, see infra notes 60-82 and accompanying text, confers upon judges and justices a power to make determinations of what would be legally "best" in a sense that depends partly on moral or policy judgments. See infra notes 135-137 and accompanying text; see also Richard H. Fallon, Jr., Precedent-Based Adjudication, Acceptance, and the Rule of Recognition, in Matthew D. Adler \& Kenneth Einar Himma, The Rule of Recognition and the U.S. Constitution 47, 59-60 (forthcoming 2009 from Oxford University Press) (developing this argument). Although judgments concerning the legally best answers in hard cases may be controversial, I follow Professor Dworkin in assuming that acknowledgment of controversy should not disable judgments of correctness in constitutional law any more than it does in morals. See Ronald Dworkin, Objectivity and Truth: You'd Better Believe It, 25 PHIL. \& PuB. AfF. 87 (1996).

32. See, e.g., Frederick Schauer, Has Precedent Ever Really Mattered in the Supreme Court?, 24 Ga. St. U. L. Rev. 381, 391-96 (2007) (examining the role of the "felt obligation" to follow precedent in the Supreme Court).

33. See, e.g., Dan Simon, Freedom and Constraint in Adjudication: A Look Through the Lens of Cognitive Psychology, 67 Brook. L. Rev. 1097, 1129 (2002) (advancing a cognitive psychological account of "the discrepancy between the openness that is apparent in the legal materials and the judicial claim of being constrained by them").

34. Because the psychological sense of constraint can sometimes diverge from the social fact-based norms in which it is rooted, and because reasonable disagreement about the content of those norms sometimes exists, it is entirely imaginable that one justice of the Supreme Court might feel normatively obliged to uphold a claimed constitutional right that another justice would feel normatively constrained to reject. See generally Ronald DwORKIN, Law's EMPIRE (1986) (explaining how theoretical disagreement in law is consistent with the view that legal questions have one right answer); Wayne D. Moore, Reconceiving Interpretive Autonomy: Insights from the Virginia and Kentucky Resolutions, 11 Const. Comment. 315, 345 (1994) (arguing that "the rule of law is promoted by the Constitution's being flexible enough to allow different persons ... to act based on diverging interpretive positions"); Simon, supra note 33, at 1112, 1129 (explaining how judges can feel constrained to adopt a particular interpretation even when the legal materials manifestly permit different interpretations).

35. In philosophy, such norm-skepticism is sometimes called "psychological egoism." See, e.g., Joel Feinberg, Psychological Egoism, in REASON AND ResPonsibILITy 497, 497 (9th ed. 1996) ("[A]ll human actions when properly understood can be seen to be motivated by selfish desires.”); Michael Anthony Slote, An Empirical Basis for Psychological Egoism, 61 J. PHIL. 530 
contrary to self-interest only proves that she must have thought, given her tastes and preferences, that it actually was in her self-interest to act as she did. ${ }^{36}$

Despite the difficulty of offering proofs that would satisfy a deep skeptic that human behavior is not always self-interested, the evidence of people being motivated by norms, including legal norms, seems too pervasive for the normskeptic's challenge to arouse much concern. As Jon Elster has pointed out, the practice of explaining behavior by appeal to norms would presumably cease if people, based on their own experiences, did not find norm-based accounts credible. $^{37}$ Furthermore, it is easy to cite examples that give every outward appearance of being norm-based behavior in the constitutional domain. As insider accounts of the Bush administration have made clear, some officials risked and lost their jobs for refusing to give the legal and constitutional advice that other, higher officials hoped to get. ${ }^{38}$ Congressional history includes notable "profiles in courage" by members who hazarded their political careers in order to perform their duties as they perceived them. ${ }^{39}$ More mundanely, the alignments of Supreme Court justices in a number of demonstrably contestable cases-with both conservatives and liberals sometimes dividing unpredictably-belie suggestions that the justices always merely vote their political preferences, rather than responding to a sense of constitutional obligation. $^{40}$

As Madison explained in The Federalist 51, however, it surely would be a mistake to assume that the Constitution is enforced-or that officials are constrained-by normative constraints alone. Rather, the Constitution creates institutions - including the electorate - that are empowered to establish nonnormative or "external” constraints on official action. Madison had what I call

(1964). Norm skepticism also emerges in certain theories of cultural evolution. See, e.g., RicHARD Dawkins, The Selfish Gene (1st ed. 1976). The most prominent analogs in legal scholarship emerge in law and economics - which tends to explain human behavior and evaluate legal interventions solely in terms of self-interest and welfare effects-but sophisticated accounts rely only on the predictiveness of self-interest, not on any deep, psychological claim about human motivation. See, e.g., Richard A. Posner, Rational Choice, Behavioral Economics, and the Law, 50 Stan. L. Rev. 1551, 1558-67 (1998) (discussing possible role for norms of fairness in economic theory); Gary S. Becker, The Economic Way of Looking at Life 1 (Univ. of Chi. John M. Olin Law \& Econ., Working Paper No. 12 (2d series), 1993), available at http://www.law.uchicago.edu/Lawecon/WkngPprs_01-25/12.Becker.Econ.pdf (describing economics as "a method of analysis, not an assumption about particular motivations").

36. See, e.g., Joel Feinberg, Psychological Egoism, in Ethical Theory 183, 183 (Russ Shafer-Landau ed., 2007) ("In short, purely altruistic and benevolent actions and desires do not exist; but people sometimes appear to be acting unselfishly and disinterestedly when they take the interests of others to be means to the promotion of their own self-interest.”).

37. See Jon Elster, Social Norms and Economic Theory, 3 J. Econ. PersP. 99, 103-04 (1989).

38. See, e.g., GoldSMith, supra note 5, at 10-11; MAYER, supra note 5, at 308.

39. See, e.g., John F. Kennedy, Profiles in Courage (1st ed. 1956).

40. See Thomas M. Keck, Party, Policy, or Duty: Why Does the Supreme Court Invalidate Federal Statutes?, 101 Am. PoL. ScI. Rev. 321, 336 (2007). 
"external constraints" in mind ${ }^{41}$ when he said that "ambition must be made to counter ambition" and praised the strategy of "divid[ing] and arrang[ing] the several offices in such a manner that each may be a check on the other." 42

Unlike normative constraints, external constraints do not function by inspiring officials with a sense of legal or moral obligation. Instead, external constraints inhere in the unwanted consequences that failure to comply with the law, or at least with expectations that are traceable to the Constitution, would frequently engender. ${ }^{43}$ In some cases, officials may be externally constrained to obey by the threat of sanctions. In others, officials may be externally constrained because they know that failure to comply with legal requirements for the valid exercise of their power would result in their acts being treated as legal nullities.

In the constitutional system as imagined by Madison, the distinction between normative and external constraints was in theory dramatically stark. When one official or branch of government checked or constrained another, Madison imagined that the checking institution, as much as the one attempting to overreach its constitutional powers, might be motivated by "private interest" rather than a sense of constitutional duty. ${ }^{44}$ Among the puzzles generated by his account, Madison never adequately explained how a continuing competition among purely selfish interests could be expected to produce adherence to constitutional norms. ${ }^{45}$ In arguing that it would, Madison apparently relied on the assumption that the interests of officials in the different branches would align with their branches' long-term interest in maintaining at least as much power as the Constitution gave them. But there is little reason to assume that otherwise wholly self-interested officials would identify their private interests with the long-term interests of a particular branch of government-rather than promoting or acquiescing in whatever distribution of power would best promote their ideological or electoral interests at any particular time. ${ }^{46}$ For example, a purely self-interested senator could be expected to acquiesce in

41. He used the term somewhat differently, however. See supra note 23.

42. The Federalist No. 5I, supra note 21, at 322.

43. External constraints are the sole focus of those who deploy rational choice or economic analysis. See, e.g., John O. McGinnis, Constitutional Review by the Executive in Foreign Affairs and War Powers: A Consequence of Rational Choice in the Separation of Powers, LAW \& Contemp. Probs., Autumn 1993, at 293, 295-305. For pioneering explorations of how strategic or game theoretical assumptions regarding human motivation might be incorporated into a basically Hartian framework, see Jules L. Coleman, The Practice of Principle 92-95 (2001); Gerald J. Postema, Coordination and Convention at the Foundations of Law, 11 J. LEGAL STUD. 165, 182-97 (1982). For an interesting discussion suggesting that positive political scientists should have a place for the internal point of view in their theories, see Ferejohn, supra note 12.

44. Id.

45. See Adrian Vermeule, Systemic Effects and the Second-Best Constitution (unpublished manuscript on file with the author; forthcoming 2009 in the Harvard Law Review).

46. See Daryl Levinson, Empire-Building Government in Constitutional Law, 118 HARv. L. REV. 915 (2005) (critiquing the assumption that government officials characteristically wish to expand the authority of the institutions of government in which they serve). 
assertions of executive power whenever she was in ideological sympathy with the executive branch and in assertions of judicial power that advanced her political agenda.

If the Madisonian system works even approximately as Madison expected, it must be because some officials, some or even most of the time, adopt an internal point of view on constitutional norms in determining when to check the attempted actions of other officials or other branches of government. For the reasons that I gave above in defending the idea that officials can and do engage in norm-based behavior that is otherwise contrary to their self-interest, ${ }^{47} \mathrm{I}$ assume in this Article that internal and external constraints on official action will typically align with and reinforce one another in ways that I shall try to explain.

Nevertheless, it is important to recognize that normative and external constraints theoretically could, and sometimes may, conflict or compete with one another. Conflict can occur if an institution that is constitutionally empowered to enforce constitutional norms instead uses its sanctioning powers for selfish, partisan, or otherwise unconstitutional purposes. In addition, even when constitutionally empowered actors proceed in good faith, they may err in their constitutional judgments. In cases in which institutions empowered to enforce constitutional norms either ignore their constitutional duties or act in error, an official may be externally constrained by the prospect of being sanctioned for actually adhering to constitutional norms.

Consider, for example, the situation of a state court judge who expects to be voted out of office if she enforces unpopular constitutional norms, or an executive official who would be sanctioned by her superiors if she did not engage in constitutionally forbidden interrogation techniques. In these cases, it is tempting to say that the external constraints confronting the official-the anticipated, unwanted consequences that may ultimately play a large role in determining her behavior-are not genuinely constitutional constraints because they do not accurately reflect constitutional norms. But if the answer to the question "How does the Constitution constrain?" is to refer to the Constitution's empowerment of officials and institutions with the capacity to visit unwanted consequences on officials who are perceived to have violated constitutional norms, then it must be recognized that the Constitution's deliberately selected constraining mechanisms will, inevitably, misfire from time to time. Whoever the ultimate enforcer is, the ultimate enforcer may err. As Justice Robert Jackson famously said of the Supreme Court, "We are not final because we are infallible, but we are infallible only because we are final., ${ }^{48}$

A central assumption of this Article is that insofar as the Constitution

47. See supra notes 37-40 and accompanying text.

48. Brown v. Allen, 344 U.S. 443, 540 (1953) (Jackson, J., concurring). 
gives rise to expectations about how officials can acceptably behave, and insofar as it creates or supports institutions capable of visiting adverse consequences on officials who do not comply with their perceived duties or otherwise depart from accepted patterns of behavior, the resulting constraints on official action ought to count as "constitutional constraints." In other words, the Constitution performs part of its constraining function by constituting, empowering, and supporting a network of mutually reinforcing institutions with the capacity to visit unwanted consequences on officials who would otherwise not comply with constitutional norms.

When the basic distinction between normative and external constraints is drawn, subcategories of both can be distinguished, and their interactions can be traced. Among the reasons that normative theorists should pay attention to external constraints is that, as Part II begins to explain, external constraints may play important roles not only in determining some officials' behavior, but also in shaping those officials' understandings of what they are normatively constrained to do and not to do.

Part III of this Article deploys the conceptual apparatus developed in Part II to examine constitutional constraints on judges and especially Supreme Court justices. Part IV then addresses the nature and bite of the constitutional restraints confronting nonjudicial officials.

Contrasting the constitutional constraints on the judiciary with those on nonjudicial officials reveals interesting asymmetries. Perhaps the most striking is that the widely recognized authority of the Supreme Court definitively "to say what the law is ${ }^{\prime 49}$ means that most officials are constrained to follow the Court's directives, even when they believe that the Court has erred, while the Court is not symmetrically constrained. On the surface, this asymmetry might suggest a constitutional preference for government by judiciary. ${ }^{50}$ At a deeper level, however, it reveals a more substantive premise, rooted in the Constitution, that helps explain a good deal about the overall structure of constitutional constraints: the Constitution embodies the assumption, whether right or wrong, that presidential and legislative action is more dangerous than presidential and legislative inaction and, accordingly, that presidential and congressional action should be subject to an especially dense network of constitutional constraints.

Before proceeding further, I should acknowledge a limitation on the scope of my inquiry that may disappoint some readers. In this Article, I offer a conceptual mapping of different kinds of normative and external constraints, and advance some non-quantitative hypotheses about how they interact with one another, but I make no effort to assess their absolute or relative significance

49. Marbury v. Madison, 5 U.S. (1 Cranch) 137, 177 (1803).

50. For a brief introduction to the idea of government by judiciary, see Frederick Schauer, The Supreme Court, 2005 Term, Foreword: The Court's Agenda-and the Nation's, 120 HaRv. L. Rev. 4, 5 \& n.1 (2006). 
in motivating particular officials. To do so would require empirical studies that lie far beyond my ambition in this Article. It will be more than enough if this Article provokes others to explore the relations between normative and nonnormative constraints on official action in constituting and sustaining the American constitutional order.

\section{CONSTITUTION AND CONTEXT: ESTABLISHING THE LIMITS OF THE INQUIRY}

In order to think about how and to what extent the Constitution constrains official behavior, it is necessary to consider the relationship between constitutional rules, on the one hand, and officials' goals and motivations, on the other hand. ${ }^{51}$ Officials undoubtedly have some goals that are largely independent of or exogenous to the constitutional structure. Fame and wealth occupy this category. Many, including some judges, may also have political or ideological agendas. $^{52}$ Some may prefer to avoid arduous work or the obloquy that comes with taking positions different from those of their families, parties, friends, or co-religionists. With officials having goals such as these, we can think of many constitutional rules as seeking to regulate or constrain officials' pursuit of their personal satisfaction.

We will go wrong at the outset, however, if we imagine that the Constitution characteristically or most fundamentally constrains officials in the same way that regulative rules such as prohibitions against murder constrain those who would otherwise commit homicides. In the absence of laws forbidding murder, people would presumably have the same power to threaten others that they have now, but they would be less constrained from taking deadly actions because of the lack of legal consequences. By contrast, in the absence of constitutional constraints on presidents and Supreme Court justices, we would not have constitutionally unconstrained presidents and Supreme Court justices. Instead, we would have no officials corresponding to what we today call presidents and Supreme Court justices. ${ }^{53}$

51. For prominent discussions of this topic, see, for example, LAwrence Baum, JudGES And Their Audiences 10-14 (2006); Epstein \& Knight, supra note 12; Richard A. Posner, Overcoming Law 135-44 (1995); Richard A. Posner, What Do Judges and Justices Maximize? (The Same Thing Everybody Else Does), 3 Sup. CT. Econ. Rev. 1 (1993).

52. See, e.g., Epstein, supra note 15, at 592 n.27 (noting that "[m]any strategic accounts of judicial decisions” make this assumption).

53. Philosophers sometimes distinguish between "constitutive rules," which "create or define new forms of behavior," and "regulative rules," which "regulate a pre-existing activity, an activity whose existence is logically independent of the rules." JOHN R. SEARLE, SPEEch ACts 33-34 (1969) [hereinafter Searle, Speech Acts]. See, e.g., Anthony Giddens, The Constitution of Society 18 (1984); Searle, Construction, supra note 30; Christopher Cherry, Regulative Rules and Constitutive Rules, 23 PHIL. Q. 301 (1973). For criticism of the view that regulative and constitutive rules are truly distinct, see JOSEPH RAZ, PracticAL REASON AND NoRMS 108-11 (1990). 


\section{A. The Conceptual Link Among Constraint, Constitution, and Empowerment}

The Constitution constrains officials most fundamentally and pervasively by helping create the context - including the official roles or offices - in which questions of constitutional constraint and even some questions of official motivation arise. ${ }^{54}$ The president cannot enact laws and the courts cannot establish national economic or defense policies. If we ask why, the answer is that to be a judge or a president is to have certain recognized and lawful powers, but not others. By constituting the offices of president and Supreme Court justice, for example, the Constitution helps establish widely accepted understandings of what presidents and justices can (and cannot) lawfully do. These understandings then function as constraints. Many, if not most, attempted exercises of purported powers that have not actually been conferred, if even thinkable, would be treated as nullities at best and might in some cases trigger the imposition of sanctions-matters that I discuss at length below.

An analogy may drive home the point. Asking whether the Constitution constrains judges or presidents is like asking whether the rules of baseball constrain a batter from running directly to second base before going to first. Although the answer in one sense may be yes, the most fundamental function of the rules of baseball is to constitute the game. Once those rules are in place, they can constrain behavior in one sense, but constraint of players and constitution of the game are too closely bound up for the question whether the rules constrain to be independent of questions involving what those rules authorize players to do and what goals they countenance. ${ }^{55}$ Because the

54. On the constitutive function of constitutions, see, for example, Holmes, supra note 1, at 163; Ernest A. Young, The Constitution Outside the Constitution, 117 Yale L.J. 408 (2007). Andrei Marmor, Legal Conventionalism, 4 LEgal Theory 509 (1998), similarly argues that the jurisprudential concept of a "rule of recognition," which I discuss at infra notes 63-82 and accompanying text, should be regarded as a "constitutive convention."

55. See Searle, Speech Acts, supra note 53, at 33-34 ("The rules of football or chess, for example, do not merely regulate playing football or chess, but as it were they create the very possibility of playing such games. The activities of playing football or chess are constituted by acting in accordance with (at least a large subset of) the appropriate rules.”); W. Bradley Wendel, Lawyers, Citizens, and the Internal Point of View, 75 FordHam L. Rev. 1473, 1485 (2006) ("Actually participating in a meaningful, purposive social practice, as opposed to dressing up and pretending to participate in it, requires accepting as mandatory the standards that regulate the practice.”).

In a recent book, Judge Posner frequently refers to "rules" of law and of judging, but notes that whereas "[i]f you do not play chess by the rules, you are not doing anything," the situation is different with respect to judging: "If you do not play judging by the rules, but instead act like a politician in robes, you are doing something, and it may be something you value more than you do the game of judging as it is supposed to be played.” Posner, supra note 9, at 91. Although there is something to this contrast, it is not as stark as Judge Posner maintains. On the one hand, someone may cheat at chess (or any other game) in order to win, and by earning recognition, the victor is doing something, not nothing. On the other hand, a judge who did something that was clearly ultra vires-for example, ordering the Internal Revenue Service to withdraw a tax assessment against her or directing the Federal Reserve Board to lower interest rates-would not be viewed as having acted with the authority of law and, in that sense, would have done "nothing" within "the game of 
Constitution helps constitute the institutional and cultural framework in which judges and presidents experience both power and constraint, there is no independent baseline of non-constraint from which to measure the constitutional constraints on judges or presidents. ${ }^{56}$

The matrix of constitutionally established roles not only shapes and limits what officials can do, but presumably also influences what they want to do. ${ }^{57}$ Imagine a person who aspires to be president or a Supreme Court justice. These goals are obviously not unrelated to interests in fame, power, and political ideology. But a person who wants to be president or a Supreme Court justice will probably not seek that office merely as a means to achieve fame or power or to advance her ideology. Much more likely, she will want to occupy that position, defined as it is, with the opportunities to achieve fame or power or advance her ideology that it affords. ${ }^{58}$

To summarize: we cannot answer the questions whether and how the Constitution constrains officials without simultaneously inquiring how and to what extent the Constitution both empowers officials and helps to define plausible goals. To think lucidly about how the Constitution constrains public officials such as judges and presidents, we must constantly keep in mind that the Constitution not only constitutes the offices of judge and president, but also lies at the foundation of an interlocking network of roles and role-based

judging." $I d$.

56. See Holmes, supra note 1, at 163 (observing that "constitutional rules are enabling, not disabling").

57. See Posner, supra note 9, at 45 ("Lower-court judges follow Supreme Court precedent . . . because ... adhering to precedents created by a higher court is one of the rules of the judicial 'game' that judges internalize.”); Whittington, supra note 16, at 615 (“Institutions do not merely impose constraints on choices; they constitute preferences."); Stephen Skowrenek, Order and Change, 28 PoLiTy 91, 94 (1995) (observing that "institutions do not simply constrain or channel the actions of self-interested individuals, they prescribe actions, construct motives, and assert legitimacy"). For a review of some of the positions in the psychological literature seeking to explain how roles influence behavior, see B.J. Biddle, Recent Developments in Role Theory, 12 ANN. Rev. Soc. 67 (1986).

58. See, e.g., Keith E. Whittington, Political Foundations of Judicial Supremacy 20 (2007) (noting that constraints on presidential power "may . . . be sufficiently internalized so as to shape the types of goals that the president formulates in the first place"). Having become president or a Supreme Court justice, a person who aspired to one of those offices is likely to adopt an institutional perspective and sense of mission, involving the norms by which presidents and justices ought to behave within the framework of American law. See, e.g., Howard Gillman, The Court as an Idea, Not a Building (or a Game): Interpretive Institutionalism and the Analysis of Supreme Court Decision-Making, in Supreme Court Decision-Making, supra note 16, at 65, 74; Smith, supra note 16, at 94.

I do not, of course, mean to imply that there will be perfect agreement about institutional roles. Nor do I mean to deny that those seeking or occupying roles at a particular time might believe that the powers currently associated with their offices should be either curbed or expanded. To take one recent example, some high-level officials in the Bush White House appear to have had the goal of restoring presidential powers that they thought had been wrongly diminished or had atrophied. See, e.g., MAYER, supra note 5, at 58-61. But there is an important distinction between having a contestable conception of appropriate limits on institutional roles and seeking to transcend such constraints altogether. 
expectations in which judges and presidents function. Somewhat more specifically, the Constitution establishes a system of legal norms that (1) constitutes the United States and its government, (2) empowers government officials, (3) imposes duties on those officials, (4) establishes structural limits on the authority of particular institutions and officials, and (5) regulates officials' discharge of their functions by creating substantive and procedural rights against them. ${ }^{59}$ In order to talk meaningfully about constitutional constraints in this Article, I therefore use the word "constraint" in an enlarged sense. So used, it reflects the Constitution's roles in supporting broadly shared understandings of lawful and unlawful official acts and, thus, in defining meaningful official goals.

\section{B. Constitutional Constraint and Constitutional Acceptance}

Although I have asserted that the Constitution constrains largely by constituting and empowering, I have not yet pressed the question how the Constitution acquires its capacity to constitute, empower, and constrain. The short answer is that the Constitution can achieve these effects because it is accepted as authoritative. ${ }^{60}$ If we ask why the Constitution is law in the United States, but the decrees of the British Parliament and the Articles of Confederation no longer possess that status, the answer is that the former is accepted as law here and the latter are not. ${ }^{61}$ As will soon become clear, however, the nature and extent of the Constitution's acceptance require examination. For this purpose, I shall begin with the general jurisprudential account offered by H.L.A. Hart in The Concept of Law, ${ }^{62}$ but will adapt it to my inquiry into constitutional constraints within the American legal system.

According to Hart, the "acceptance" necessary to sustain a legal system comes from governmental officials, especially judges. ${ }^{63}$ More specifically, Hart posits that judges must adopt an "internal point of view" on the "rules of

59. Cf. Ernest A. Young, The Constitutive and Entrenchment Functions of Constitutions: A Research Agenda, 10 U. PA. J. Const. L. 399, 400-01 (2008) (characterizing "the institutioncreating and rights-conferring functions" of constitutions as "to at least some extent flip-sides of another" and thus properly grouped under the heading of "the 'constitutive' function").

60. See Frederick Schauer, Precedent and the Necessary Externality of Constitutional Norms, 17 Harv. J.L. \& Pub. POL'y 45, 51-53 (1994) (arguing that the "ultimately validity" of the Constitution is "not itself a constitutional question, but a political and sociological one").

61. See Richard H. Fallon, Jr., Constitutional Precedent Viewed Through the Lens of Hartian Positivist Jurisprudence, 86 N.C. L. REv. 1107, 1128-29 (2008).

62. HART, supra note 17.

63. Id. at 256 (stating that "the rule of recognition . . . is in effect a form of judicial customary rule existing only if it is accepted and practised in the law-identifying and law-applying operations of the courts"); see also id. at 116 (asserting that the "rules of recognition specifying the criteria of legal validity and [the legal system's] rules of change and adjudication must be effectively accepted as common public standards of official behaviour by its officials"). By contrast, Hart said, "[t]he ordinary citizen manifests his acceptance largely by acquiescence.” Id. at 61 . 
recognition” that establish the criteria for identifying valid and binding law ${ }^{64}$ : judges must regard the socially established and prevailing rules for identifying legal rights, powers, and obligations as "common standards of official behavior and appraise critically their own and each other's deviations as lapses." ${ }^{.65}$ For example, they must regard bills duly passed by both houses of Congress and signed by the president as law unless those bills run afoul of some applicable constitutional prohibition by, for example, discriminating on the basis of race or gender.

In the United States, as in other legal systems, not all of the criteria for legal validity—especially those used by judges in legal interpretation—can be authoritatively written down. Any effort to list them definitively would lead to infinite regress: questions would endlessly arise concerning what rules to use in interpreting ostensibly ultimate interpretive rules. ${ }^{66}$ In addition, it must be acknowledged that American constitutional practice is deeply argumentative, ${ }^{67}$ with Supreme Court justices notoriously disagreeing with each other in some cases about the criteria by which valid constitutional claims should be distinguished from invalid ones. In the well-known view of Ronald Dworkin, disagreement among judges and justices concerning the purported rules of recognition suffices to demonstrate that their conduct is not rule-governed at all. $^{68}$

In my view, it is important to make neither too much nor too little of constitutional disagreement. Although some irreducible disagreement undoubtedly exists, there is also enough consensus so that issues of constitutional validity arise relatively rarely. No one doubts that most of the content of the statute books constitutes valid law. Even with respect to matters about which constitutional issues could obviously be raised, nearly all judges and justices frequently converge in their judgments, even if they disagree about why those judgments are correct. For example, some may think that the holding of Brown v. Board of Education ${ }^{69}$ is valid law binding on the Supreme Court because it correctly reflects the original understanding of the Equal Protection Clause, and others because it is settled precedent, even if it does not correctly reflect the original understanding of the Fourteenth Amendment. For cases not resolved by consensus understandings, Jules Coleman has described the rule of recognition as a conventional "framework for bargaining.,"70 If Coleman is

64. Id. at $116-17$.

65. Id.

66. See Laurence H. Tribe, Comment, in Antonin Scalia, A Matter of INTERPRETATION 65, 77-78 (Amy Gutmann ed., 1997).

67. See Dworkin, supra note 34, at 13 ("Legal practice, unlike many other social phenomena, is argumentative.").

68. See Ronald Dworkin, Taking Rights Seriously $39-45$ (1977) (arguing that Hart's account of the rule of recognition as the "master rule" of a legal system is untenable).

69. 347 U.S. 483 (1954).

70. See Coleman, supra note 43 , at 100 . 
correct, then in many of the disputed cases that come before the Supreme Court, the justices not only can, but sometimes must, base their decisions on controversial views concerning how pertinent authorities would best be interpreted, applied, or implemented. ${ }^{71}$

Although methodological disagreement in high-profile cases should not blind us to the phenomenon of widespread convergence in the vast, too often overlooked category of "easy" constitutional cases, ${ }^{72}$ challenges such as Dworkin's make clear that references to constitutional interpretation as governed by "rules" must employ that term in a distinctively capacious sense. For the Hartian idea of a "rule of recognition" to fit the American legal system, the concept of a rule needs to encompass not just rules as defined by Dworkin - rigid dictates that either apply or do not apply and tolerate no accommodation of competing considerations ${ }^{73}$-but the whole range of sometimes inarticulate criteria employed in legal decision-making. Perhaps more broadly still, many of the pertinent rules of recognition may be "rules" only in the sense made famous by the philosopher Ludwig Wittgenstein: they mark a shared and often tacit understanding among some relevant group concerning how to "go on" in ways that will be acknowledged by others in the group as appropriate or correct. ${ }^{74}$ According to an account of rule-following that Hart embraced, ${ }^{75}$ "the test of whether a man's actions are the application of a rule is not whether he can formulate it but whether it makes sense to distinguish between a right and a wrong way of doing things in connection with what he does." 76

When the term "rule" is used this loosely, there is undoubted and perhaps irreducible risk that it will be misunderstood. Perhaps it would be better to develop a richer and more precise vocabulary than Hart's references to rules and a rule of recognition provide. Nevertheless, Hart seems to me to have been basically correct in suggesting that even the sharpest substantive and methodological disputes in constitutional law occur against the background of widely shared normative understandings, many of which are more tacit than express, and that the range of reasonable positions is bounded even in most cases of disagreement.

71. See infra notes $135-137$ and accompanying text.

72. See Frederick Schauer, Easy Cases, 58 S. CAL. L. Rev. 399, 408-14 (1985).

73. See Dworkin, Taking Rights Seriously, supra note 68, at 24 ("Rules are applicable in an all-or-nothing fashion.”).

74. See Ludwig Wittgenstein, Philosophical Investigations para. 151-53, 179-83 (G. E. M. Anscombe trans., 1953); see also Coleman, supra note 43, at 81 (invoking the Wittgensteinian notion to explicate jurisprudential issues). For explorations of Wittgenstein's views about the nature of rule-following, see Wittgenstein: To Follow a Rule (Steven H. Holtzman \& Christopher M. Leich eds., 1981); SaUl KripKe, Wittgenstein on Rules and Private Language: An Elementary Exposition (1982).

75. See HART, supra note 17, at 289.

76. Peter Winch, The Idea of a Social Science and Its Relation to Philosophy 58 (1958). 
Applied to the Constitution of the United States, Hart's framework implies that public officials and especially judges typically regard the Constitution and other, surrounding norms of legal validity as guides to their own conduct and as grounds for criticizing others. Both judges' own accounts ${ }^{77}$ and psychological theories stressing the importance of socialization and social roles in influencing human behavior ${ }^{78}$ attest to the plausibility of claims that judges seek to comply with distinctively legal obligations. Judges and justices are deeply socialized, beginning with their training as law students, to believe that there are legal norms independent of personal preference and that judges have an obligation to do what the law requires. ${ }^{79}$ Indeed, legal norms may become so deeply internalized that the prospect of deviating from them would simply never enter a judge's mind in many, perhaps even most, cases. For those who have internalized norms, those norms frequently determine behavior. ${ }^{80}$

According to Hart, ordinary citizens need not "accept" the "rules of recognition" by which binding law is identified in the same active sense as do judges; it suffices that ordinary citizens acquiesce to officials’ practices. ${ }^{81}$ It is

77. See, e.g., Texas v. Johnson, 491 U.S. 397, 420-21 (1989) (Kennedy, J., concurring) (explaining that the Court's decision, which held that a conviction for flag burning violated the First Amendment, "exacts its personal toll," but that "sometimes we must make decisions we do not like," because "they are right, right in the sense that the law and the Constitution, as we see them, compel the result”); Griswold v. Connecticut, 381 U.S. 479, 527 (1965) (Stewart, J., dissenting) (explaining that while the ban on contraceptives was "an uncommonly silly law," the Court was "not asked ... to say whether we think this law is unwise, or even asinine," but whether "it violates the United States Constitution"); Confirmation Hearing on the Nomination of Samuel A. Alito, Jr. to be an Associate Justice of the Supreme Court of the United States: Hearing Before the S. Comm. on the Judiciary, 109th Cong. 56 (2006) (statement of Samuel A. Alito, Jr.) ("The judge's only obligation —and it's a solemn obligation —is to the rule of law. And what that means is that in every single case, the judge has to do what the law requires."); BENJAMIN N. CARDOzo, The Nature of the Judicial Process 114 (1921) (describing the constraints on judicial creativity "established by the traditions of the centuries, by the example of other judges, ... by the collective judgment of the profession, and by the duty of adherence to the pervading spirit of the law"); Henry J. Friendly, Judicial Control of Discretionary Administrative Action, 23 J. Legal EDuc. 63, 64 (1970) (citing Lord Halsbury and Chief Justice Marshall for a view of law-bound discretion that "sounds remarkably like what judges do, or think they do").

78. For a survey of such theories, see Biddle, supra note 57.

79. See, e.g., Mark Tushnet, Constitutional Interpretation, Character, and Experience, 72 B.U. L. Rev. 747, 751 (1992) (emphasizing "limits on what properly socialized judges do"); Adrian Vermeule, Instrumentalisms, 120 Harv. L. Rev. 2113, 2132 (2007) (reviewing Brian Z. Tamanaha, Law as a Means to an End (2006)) ("[T]he internalized sense of legal rulefollowing by officials and the public ... is part of what we call 'the rule of law.'”).

80. See, e.g., Christine Horne, The Internal Enforcement of Norms, 19 Eur. Soc. Rev. 335 (2003); Dan M. Kahan, What Do Alternative Sanctions Mean?, 63 U. CHI. L. Rev. 591 (1996); Lawrence Lessig, The Regulation of Social Meaning, 62 U. CHI. L. Rev. 943 (1995); Richard A. Posner, Social Norms and the Law: An Economic Approach, Am. Econ. Rev., May 1997, at 365, 365 (explaining that judges follow "norms governing judicial behavior," because failing to do so means "not playing the judicial 'game,"” and the "judicial selection procedures select for persons who want to play the judicial game"); Symposium, The Legal Construction of Norms, 86 VA. L. REv. 1577 (2000).

81. See HART, supra note 17, at 60-61 (considering the acquiescence of ordinary citizens as part of "the complex phenomenon which we call the existence of a legal system"). 
possible, however, for ordinary citizens to accept the Constitution in a more active sense and to treat officials' failures to observe constitutional norms as occasions for reproach. By all appearances, many citizens of the United States hold this normative attitude. ${ }^{82}$ If many or even most citizens regard officials' deviations from constitutional norms as deserving of rebuke, the practical implications can be enormous.

In contrast with the "internal point of view" of those who regard the Constitution as furnishing reasons for action, Hart, as noted above, posited the existence of an "external" point of view. ${ }^{83}$ For current purposes, it involves the perspective of someone who does not regard constitutional norms as inherently authoritative for her, but who wishes to understand and anticipate how others will identify and react to violations of the law. ${ }^{84}$ So described, Hart's external point of view approximates the attitude that some political scientists, employing a rational choice or game theoretical methodology, depict as underlying officials' conformity to the Constitution. ${ }^{85}$

These positive theorists believe that what I characterized above as legal "norms" are in fact non-normative equilibria, reflecting rational calculations by a myriad of actors concerning how-in light of the expectations and likely reactions of others-it is in their rational self-interest to behave. ${ }^{86}$ According to these theorists, the Constitution represents the solution to a coordination problem involving the interests of a multitude of actors: "The Constitution of

82. See, e.g., Thomas C. Grey, The Constitution as Scripture, 37 Stan. L. Rev. 1, 17 (1984) (noting "the well-attested phenomenon of American constitution-worship").

83. HART, supra note 17 , at $88-89$.

84. Hart used the term "external point of view" in multiple senses: sometimes to refer to the outlook of someone concerned only with predicting behavior and wholly unconcerned with motivations, see id. at 86-89, sometimes to refer to the hermeneutic perspective of a person who grasps the rule an identifiable group applies but does not accept or endorse it, see id. at 89 , and sometimes to describe the outlook of a Holmesian "bad man" who accords rules no normative significance but may nevertheless conform to them in order to avoid sanctions, see id. at 39. For a lucid brief discussion of Hart's varying conceptions of the external point of view, see Shapiro, supra note 26, at 1159-61. The most crucial distinction between the internal and external points of view is that those who take the former view accept rules as reason-giving for them, whereas those who take the external point of view do not.

85. See, e.g., Russell Hardin, Liberalism, Constitutionalism, and Democracy 12 18, 87-90, 97-98, 139-40 (1999) (describing the Constitution as a "self-enforcing" coordination convention); Peter C. Ordeshook, Constitutional Stability, 3 Const. Pol. Econ. 137 (1992); McNollgast, supra note 12, at 1668 ("[I]n our theory, doctrinal stability and the rule of law do not derive from first principles or the beliefs and values of judges but from the equilibrium between the political branches and the judiciary.”); Epstein, supra note 15, at 585 ("We argue that, given the institutional constraints imposed on the Court, the Justices cannot effectuate their own policy and institutional goals without taking account of the goals and likely actions of the members of the other branches.”).

86. See Ordeshook, supra note 85 , at 150 ("[I]f [a constitution] is effective-if it coordinates action - then it must be an equilibrium in the sense that no individual within the society has an incentive and the ability to defect to some other strategy.”).

87. See Hardin, supra note 85 , at 119 ; Ordeshook, supra note 85 , at 149 ; see also Holmes, supra note 1, at 173 ("A liberal constitutional framework is a classic solution to a 
1787 worked in the end because enough of the relevant people worked within its confines long enough to get it established in everyone's expectations that there was no point in not working within its confines." mode of analysis emphasize, the observable results of self-interested action pursuant to a coordination convention (such as they take the Constitution to be) can be precisely the same as in the case of norm-guided behavior: "[S]ocially valuable goals, such as the respect for precedent and the rule of law, are a byproduct of the more narrow and limited goals [of judges and officials] of pursuing personal policy objectives ${ }^{\not 89}$ subject to the constraints arising from the likely responses of others to some moves that they otherwise might make.

Nonetheless, the underlying attitudes and motivations are strikingly different. ${ }^{90}$ In the view of those who depict the Constitution as a coordination convention, one should be extremely skeptical of claims that anyone seeks to obey the Constitution out of a sense of obligation, rather than for wholly selfinterested reasons. One should also be alive to the possibility that officials or institutions, when it would advance their self-interest and when they can get away with doing so, might occasionally threaten or impose sanctions against those who comply with, rather than deviate from, constitutional standards.

As I made clear in the Introduction, I believe that the internal point of view and the idea of normative constraints are absolutely indispensable to grasping how law in general, and how the American constitutional system in particular, function. Explanations of constitutional law as just a system of equilibria involving purely self-interested actors cannot account adequately for the law's insistent claims to normative authority. As Hart emphasized, those who view law from an internal point of view express its demands in the language of obligation, including such terms as "ought," "should," "right," and "wrong." 91 Nor, as I have said, should the motivational efficacy of such claims and understandings be discounted. ${ }^{92}$

Plainly, however, normative constraints are not always efficacious, any more in law than in morals. (A constraint-including the paradigmatic threat of criminal punishment — can remain a constraint even if it fails to determine conduct in every instance.) In addition, reasonable disagreement can exist about the content of some of the norms by which officials are bound. As much as normative constraints, external constraints thus deserve attention in any study

collective action problem.”).

88. Russell Hardin, Why a Constitution?, in The Federalist Papers and the New Institutionalism 100, 117-18 (Bernard Grofman \& Donald Wittman eds., 1989).

89. McNollgast, supra note 12 , at 1668.

90. For discussion of the implications of judges' holding these different perspectives, see Brian Z. Tamanaha, A Socio-Legal Methodology for the Internal/External Distinction: Jurisprudential Implications, 75 FordHAM L. REV. 1255 (2006).

91. See HART, supra note 17 , at 57.

92. For empirical research supporting the efficacy of internalized norms, see, for example, Horne, supra note 80 . 
of how our Constitution works in practice. ${ }^{93}$

II

\section{A Typology of CONSTITUTIONAL CONSTRAinTs}

This Part develops a typology of constitutional constraints-that is, a classificatory scheme for thinking about the ways in which the Constitution either constrains or establishes mechanisms for constraining government officials. Constraints on government officials count for my purposes as “constitutional constraints” as long as they are legal norms, or consequences arising from officials' perceived violations of legal norms, that owe their existence to the Constitution's constitutive effects. For example, sanctions for actual or purported constitutional violations are constitutional constraints as long as they are administered by constitutionally constituted entities, even if they are sanctions to which the Constitution makes no explicit reference. Although this usage is broad, it reflects my aspiration to address the questions of how and to what extent the Constitution constrains official decision-makers. A central way the Constitution constrains is by constituting or otherwise giving rise to institutions and legal practices that perform constraining functions. ${ }^{94}$

\section{A. The Internal Point of View: Direct and Indirect Normative Constraints}

Insofar as officials regard the Constitution and its surrounding rules of recognition from an internal point of view, the Constitution constrains officials

93. Bracketing as many issues as possible, I assume that normative constraints arising from perceptions of constitutional obligation function as constraints in ways analogous to those in which moral norms constrain those who accept them. For a brief but illuminating discussion, see Ferejohn, supra note 12, at 273-75; compare Biddle, supra note 57 (distinguishing norms, beliefs, and preferences as alternative explanations for conformity).

94. Once it is recognized that a text can function as law only insofar as it is embedded in a practice that makes it law, it becomes difficult, if not impossible, to give an informative account of what the Constitution is, and thus of how it constrains, without reference to the practice in which it is accepted, understood, and interpreted. In other words, references to "the Constitution" are almost inherently empty unless they signify "the written Constitution as identified and interpreted" under what H.L.A. Hart characterized as pertinent "rules of recognition"-and my references in this essay should be so understood. See HART, supra note 17, at 116-17. Although my usage in this respect may appear to reflect an internal perspective on constitutional norms, those who claim that "the Constitution" is a coordination convention confront a similar challenge of specification to which they must respond in similar ways. If, as is undoubtedly the case, prevailing understandings of congressional, executive, and judicial power have shifted over time, the question arises whether we have had one coordination convention, or many. The best answer to that question, I think, is that the idea of the Constitution as a coordination convention must acknowledge that coordination can be reasonably successful even when it is less than complete and must presuppose criteria of identity that permit evolution or change. See generally Randall Calvert \& James Johnson, Interpretation and Coordination in Constitutional Politics, in Lessons IN Democracy 99, 104 (Ewa Hauser \& Jacek Wasilewski eds., 1999) (advancing an approach that "sees a lasting constitution as an evolving convention, rather than a static one"). 
by giving them duty-based reasons not to act in particular ways. ${ }^{95}$ We can readily imagine, for example, that an official who would otherwise attempt to promote her party's prospects of winning an election might regard herself as duty-bound to forbear from doing so in ways that would violate constitutional norms. As I noted above, the existence of constitutional norms depends on broadly shared, public understandings and practices. In a fundamental sense, public officials' duties or obligations are therefore independent of what any particular official (possibly mistakenly) believes. In a functional sense, however, the Constitution's capacity to constrain depends partly on the psychological apprehensions of legal duty that it generates.

Within the category of normative constitutional constraints, a useful distinction exists between those that are direct and those that are indirect. Direct normative constraints are reflected in an official's unmediated, personal interpretation of the written Constitution or other sources of legal authority. They manifest themselves through what some scholars have termed a "Protestant" approach to constitutional law, in which each person decides for herself what the Constitution and other legal norms mean without acknowledging anyone else's interpretations as epistemically authoritative. ${ }^{96}$

Indirect normative constraints exist insofar as officials are duty-bound to treat other officials' interpretations or dictates as legally authoritative. It will be helpful to distinguish two subcategories of indirect constraints. First, insofar as the Constitution imposes an obligation on officials to accept someone else's constitutional interpretations as binding, it subjects them to mediated constraints. Significantly, it is more the norm than the exception for officials to understand themselves as constrained to accept judicial, and especially Supreme Court, interpretations of the Constitution, even if they believe that the court has erred. ${ }^{97}$ Some scholars have associated the acknowledgment of mediated constraints with a "Catholic" approach to constitutional interpretation. $^{98}$

95. See HART, supra note 17 , at 11 (asserting that to "accept" a rule is to treat it as a "reason and justification" for action).

96. See generally SANFord Levinson, Constitutional Faith 9-53 (1988); Grey, supra note 82 , at 3, 5-9.

97. For a prominent defense of the idea that officials are bound by judicial interpretations of the Constitution even when they disagree with those interpretations, see Larry Alexander \& Frederick Schauer, On Extrajudicial Constitutional Interpretation, 110 HaRv. L. Rev. 1359 (1997) [hereinafter Alexander \& Schauer, Extrajudicial Interpretation]; see also Larry Alexander \& Frederick Schauer, Defending Judicial Supremacy: A Reply, 17 Const. Comment. 455 (2000) (responding to criticism of the idea that other officials must adhere to the Supreme Court's constitutional rulings). For diverse opposing views, see, for example, Edwin Meese III, The Law of the Constitution, 61 Tul. L. Rev. 979 (1987); Sanford Levinson, Could Meese Be Right This Time?, 61 Tul. L. Rev. 1071 (1987); Michael Stokes Paulsen, The Most Dangerous Branch: Executive Power to Say What the Law Is, 83 Geo. L.J. 217, 343-45 (1994); Mark V. Tushnet, The Hardest Question in Constitutional Law, 81 MinN. L. Rev. 1, 25-28 (1996).

98. See Levinson, supra note 96, at 9-53; Grey, supra note 82, at 5-13. As I use the terms, the distinction between "direct" and "mediated" constitutional constraints is as much one of 
The second subcategory of indirect constitutional constraints consists of constitutionally authorized constraints, which result from the actions of governmental institutions in establishing valid law. The category of constitutionally authorized constraints is important insofar as officials, including judges and the president, are constitutionally obliged to enforce the law.

It is tempting to conclude that the category of constitutionally authorized normative constraints subsumes, and thus renders redundant, the category of mediated normative constraints. For example, one might say that other officials are bound by Supreme Court interpretations of the Constitution-and thus are subject to mediated constitutional constraints-insofar as the Constitution authorizes the Supreme Court to establish interpretations that bind other officials. For the moment, however, I prefer to leave open the question whether the Court should be viewed as authorized to bind other officials by promulgating erroneous interpretations, even if those erroneous interpretations subject other officials to mediated normative constraints.

\section{B. The External Point of View and External Constraints}

There are two main kinds of external constitutional constraints. One arises from recognition that some acts would fail to achieve their intended results because they would be regarded as legally inefficacious. Another constraint comes from the threat of sanctions that go beyond mere inefficacy or legal nullity.

\section{Inefficacy or Nullity Under Applicable Rules of Recognition}

Within Hart's conceptual framework, many constitutional provisions are power-conferring rules $^{99}$ that enable officials to act with the authority of law.

degree as it is of kind, for an official or institution can generate mediated obligations only insofar as it operates within its jurisdiction or is not ultra vires. Thus, for example, the Supreme Court's decisions about the constitutionality of school prayer can give rise to mediated obligations on the part of school officials, even if they believed that the Court erred, but a Supreme Court decision purporting to direct the Federal Reserve Board to raise interest rates would not give rise to mediated obligations because it lies wholly beyond the Court's jurisdiction.

The related distinction between Catholic and Protestant interpretive approaches is similarly as much one of degree as of kind. Because of the need for those inclined to the Catholic view to make judgments about the scope of officials' (and especially the Supreme Court's) authority to decide authoritatively, the Catholic view necessarily shades into the Protestant view at the margins. Correspondingly, the Protestant view is an interpretive perspective on texts, practices, and other sources of legal authority that depend for their status as sources of legal authority on collective judgment and widespread practice. Thus, while the interpretive Protestant can maintain that the view of another official or institution is not necessarily authoritative with respect to any particular constitutional question, it is impossible to define an interpretive stance toward law that is wholly insensitive to the past and present views and actions of others. For a similar but not identical characterization of interpretive Protestantism in law, see DworkIN, supra note 34, at 190, 413.

99. See HART, supra note 17 , at 27-28. 
But constitutional grants of power are seldom absolute. More frequently, they specify the scope of an official's jurisdiction to act authoritatively-that is, they authorize officials to perform some acts but not others. Power-conferring rules typically also prescribe the procedures officials must use in order to act with legal authority.

Rules of recognition that mark the outer bounds of officials' lawful authority function as external constraints on what those officials can do. ${ }^{100}$ For example, members of Congress know that if they were to pass a bill forbidding any challenger from campaigning while Congress is in session, the enactment would be a legal nullity. Similarly, if we can imagine a president who otherwise might declare unilaterally that wealthy citizens must pay higher taxes, applicable rules of recognition would externally constrain the president from doing so. Absent the enactment of legislation, the president's unilateral declaration would not be legally efficacious.

One subset of constraints that arises from publicly recognized limits on official authority merits a brief, separate discussion: concurrent agreement or concurrent acquiescence requirements. The Constitution frequently constrains public officials by making their capacity to act authoritatively depend on the formally expressed concurrent agreement or acquiescence of other officials. Members of Congress cannot legislate without the agreement of a majority of other members of both the House and Senate, as well as that of the president. ${ }^{101}$ Presidents are constrained from filling high public offices, including judgeships, by the requirement that appointments receive the consent of the Senate. $^{102}$

Although concurrent agreement requirements often have the principal purpose of promoting wise decisions, they can also help enforce constitutional norms. ${ }^{103}$ Where concurrent agreement requirements apply, multiple parties or institutions have the authority to bar actions that they think the Constitution forbids. Either house of Congress can reject legislation on constitutional grounds; Presidents can veto bills that they believe to be unconstitutional. Perhaps more interestingly, both Congress and the President may view judicial review as a concurrent agreement or acquiescence constraint.

100. See Kenneth Einar Himma, Making Sense of Constitutional Disagreement: Legal Positivism, the Bill of Rights, and the Conventional Rule of Recognition in the United States, 4 J.L. Soc'y 149, 154 (2003); see also Neal Devins, Should the Supreme Court Fear Congress?, 90 MinN. L. REv. 1337, 1341-42 (2006) (discussing effects of "implementation concerns" on Supreme Court decision-making); Friedman, supra note 10, at 295-308 (discussing the effect of the need to secure compliance from lower court judges on Supreme Court decision-making).

101. See U.S. Const. art. I, § 7, cl. 2.

102. See id. art. II, § 2, cl. 2.

103. For the argument that the Constitution aspires to protect rights by creating multiple institutions with the capacity to veto legislation that could reasonably be thought to violate rights, see Richard H. Fallon, Jr., The Core of an Uneasy Case for Judicial Review, 121 HaRv. L. Rev. 1693, 1706-07 (2008); Frank B. Cross, Institutions and Enforcement of the Bill of Rights, 85 Cornell L. Rev. 1529, 1576 (2000). 


\section{Sanctions}

The Constitution establishes a number of institutions with the capacity to impose formal sanctions such as criminal punishments, impeachments and removals from office, and dishonorable discharges from military service. In this Article, however, I use the term "sanctions" more broadly to embrace not only formally denominated penalties, but also any constitutionally authorized action by a constitutionally established institution that visits unpleasant consequences on another official or institution on the ground that he, she, or it has violated legal norms. ${ }^{104}$ Like concurrent agreement requirements, sanctions can be authorized and administered either to promote wise policies or to enforce constitutional norms.

An example of an informal sanction is an official's constituents voting her out of office partly because they believe she has violated the Constitution. ${ }^{105}$ Just as the Constitution establishes formal institutions, notably courts, with the capacity to impose sanctions, it also constitutes the electorate as a political institution. ${ }^{106}$ The political community and electoral constituencies that the Constitution establishes therefore count for some purposes as constitutionally empowered institutions capable of imposing sanctions. ${ }^{107}$

When the term "sanction" is used so broadly, the line between constitutional constraints arising from concurrent agreement requirements, on the one hand, and informal sanctions, on the other, is frequently uncertain. For example, a judicial opinion invalidating a statute or a presidential action on constitutional grounds might sometimes be plausibly assigned to either category-or to both. Most such rulings achieve their principal effect by relegating a purported assertion of governmental authority to the status of a legal nullity. But when, for example, the Supreme Court invalidated the Truman administration's 1952 seizure of the nation's steel mills, ${ }^{108}$ its decision was widely construed as a rebuke by the Court that almost certainly weakened the administration's political standing. ${ }^{109}$ Occasionally, too, the Court writes

104. See Robert Cooter, Prices and Sanctions, 84 Colum. L. Rev. 1523, 1523 (1984) (defining a sanction "as a detriment imposed for doing what is forbidden").

105. See Saikrishna Bangalore Prakash, The Executive's Duty to Disregard Unconstitutional Laws, 96 Geo. L.J. 1613, 1680 (2008) ("Voters may sanction a President whose constitutional readings the public finds distasteful.”).

106. See id. ("Incumbent Presidents can lose reelection bids based on their constitutional readings-this arguably happened to John Adams because of his vigorous enforcement of the Sedition Act.”).

107. See Richard H. Fallon, Jr., Executive Power and the Political Constitution, 2007 UtAH L. Rev. 1, 22-23 (emphasizing that the responsibility for enforcing the Constitution against the president ultimately resides with Congress and the electorate).

108. See Youngstown Sheet \& Tube Co. v. Sawyer, 343 U.S. 579, 589 (1952).

109. See David Gray Adler, The Steel Seizure Case and Inherent Presidential Power, 19 Const. Comment. 155 (2002); see also Robert G. McCloskey, The American Supreme Court 128 (4th ed. 2005) (noting that all the justices, most observers, and even President Truman agreed that the seizure of the steel mills was improper because "surely inherent executive power, 
opinions that seem calculated to chastise and thus to sanction a lower court, the judges of which are likely to suffer a diminution in esteem within the legal profession, if not in the eyes of the broader public. ${ }^{110}$ If Congress had approved President Roosevelt's Court-packing plan in $1937,{ }^{111}$ its action would also have constituted an informal sanction. Congress would not only have rebuked the Supreme Court, but also visited upon the sitting justices an unwanted loss of power. $^{112}$

The sometimes uncertain boundary between constraints arising from requirements of concurrent agreement and those arising from informal sanctions should occasion no alarm. Many robust distinctions have blurry borders: dusk and dawn do not seriously undermine the distinction between day and night. ${ }^{113}$ More pertinently, by far the most important distinction in understanding constitutional constraints is the one between normative constraints operating through individual officials' sense of duty, on the one hand, and external constraints enforced against individual officials by other officials or institutions, on the other hand.

\section{Constraint and Motivation}

Having now delineated some categories of constitutional constraints, I should like to make three further points about their relation to one another and their overall role in influencing officials' behavior.

First, constitutional constraints can sometimes be in tension with one another. Most obviously, disjunctions can develop between normative and external constraints. For example, the electorate might sanction a state court judge who is subject to reelection for fulfilling her normative obligations to enforce unpopular constitutional guarantees. ${ }^{114}$ In thinking about constitutional

even if there is such a thing, does not license the President to violate statutes").

110. An example is Vasquez v. Harris, 503 U.S. 1000, 1000 (1992), in which the Supreme Court vacated a stay of execution granted by the Ninth Circuit and further ordered summarily that "[n]o further stays of Robert Alton Harris' execution shall be entered by the federal courts except upon order of this Court.” For discussion of the Harris case, see Charles Fried, Impudence, 1992 SuP. Cт. Rev. 155. See generally Stephen L. Wasby, Accountability: "Judicial Imperialism" Revisited, 65 Judicature 209, 217 (1981) (characterizing a higher court's reversal of a lower court as a sanction).

111. For a description of the Court-packing plan, see William E. Leuchtenburg, The Supreme Court Reborn: The Constitutional Revolution in the Age of Roosevelt 8485, 96-97, 112-21, 142-43, 216-20 (1995).

112. Cf. PosNer, supra note 9, at 375 (observing that "[w]hat reins in the Justices ... is an awareness, conscious or unconscious, that they cannot go 'too far' without inviting reprisals by other branches of government").

113. Cf. H.L.A. Hart, Positivism and the Separation of Law and Morals, 71 Harv. L. Rev. 593, 614 (1958) (explaining that "even if there are borderlines, there must first be lines").

114. See, e.g., Stephen B. Bright, Political Attacks on the Judiciary: Can Justice Be Done Amid Efforts to Intimidate and Remove Judges From Office For Unpopular Decisions?, 72 N.Y.U. L. REv. 308, 312 (1997) (warning that "[c]ourts are not independent when state judges are voted off the bench because of unpopular decisions by their courts and federal judges reverse 
constraints, it is important to keep in mind that those imposing sanctions may not always apply the Constitution correctly and, in imaginable instances, might not even attempt to do so.

Second, although normative and external constraints can be in tension with one another, I believe-and will suggest in subsequent Parts of this Article - that Supreme Court justices, in particular, rarely experience a sharp sense of conflict. Among the reasons, I would speculate, is that if external constraints make it impossible for officials to do efficaciously what they believe the Constitution requires them to do, they may tend psychologically to adjust their understanding of what the Constitution requires or permits. ${ }^{115}$ Suggestive in this respect is the observation, often given the status of a precept, that "the Constitution . . . is not a suicide pact." 116 Also suggestive is the long tradition of prudential judicial decision-making, in which courts have typically avoided decisions that would provoke publicly approved defiance by the executive branch. ${ }^{117}$ This tradition originated with Marbury v. Madison ${ }^{118}$ and its companion case of Stuart v. Laird, ${ }^{119}$ in which the Supreme Court-despite assertive talk in Marbury-yielded to political threats that included judicial impeachments by rendering judgments favorable to the Jefferson administration. ${ }^{120}$ Judicial prudentialism may also help explain how, as Robert Dahl famously asserted, the Supreme Court has seldom departed very far for very long from the sentiments of aroused and durable political majorities. ${ }^{121}$

decisions or resign from the bench after a barrage of criticism”); Helen Hershkoff, Positive Rights and State Constitutions: The Limits of Federal Rationality Review, 112 HARv. L. Rev. 1131, 1159 (1999) (describing "the concern that elected judges, beholden to majoritarian support for their retention, will be reluctant to enforce unpopular rights," and citing examples involving capital punishment and state constitutional welfare issues); cf. The Federalist No. 78, at 470 (Alexander Hamilton) (Clinton Rossiter ed., 1961) (cautioning that if judges are selected by "the people . . . there would be too great a disposition to consult popularity to justify a reliance that nothing would be consulted but the Constitution and the laws").

115. Recent psychological research suggests that such corrective cognitive mechanisms affect adjudication. See, e.g., Simon, supra note 33, at 1100 (providing an account of "coherencebased" reasoning, through which "cognitive mechanisms operate to create a lopsided view of the case that provides stronger argumentative support than the legal materials would otherwise provide").

116. Kennedy v. Mendoza-Martinez, 372 U.S. 144, 160 (1963).

117. See Richard H. Fallon, Jr., Marbury and the Constitutional Mind: A Bicentennial Essay on the Wages of Doctrinal Tension, 91 CALIF. L. Rev. 1, 16-20, 27-33 (2003) (describing a strand of prudentialism in Supreme Court decision-making that traces to Marbury).

118. 5 U.S. (1 Cranch) 137 (1803).

119. 5 U.S. (1 Cranch) 299 (1803).

120. On the political maneuvering surrounding and reflected in Marbury and Stuart $v$. Laird, see Bruce Ackerman, The FaIlure of the Founding Fathers: Jefferson, Marshall, and the Rise of Presidential Democracy (2005).

121. See Robert A. Dahl, Decision-Making in a Democracy: The Supreme Court as a National Policy-Maker, 6 J. Pub. L. 279, 285 (1957); see also Robert A. Dahl, Democracy AND ITs CRITICs 190 (1989) ("[T]he views of a majority of the justices of the Supreme Court are never out of line for very long with the views prevailing among the lawmaking majorities of the country.”); McCloskey, supra note 109, at 246 ("It is hard to find a single historical instance 
If I am correct in my suggestion that officials will tend, when reasonably possible, to interpret their constitutional duties to avoid collisions with external constraints, then external constraints not only reinforce, but also help shape, officials' perceptions of their obligations. What is more, insofar as officials' perceptions of their duties are sufficiently widely shared to mark Hartian "rules of recognition,” then external constraints, by influencing officials’ beliefs, may actually play a role in defining officials' normative obligations. If all or nearly all judges and justices follow rules of recognition under which they understand the Constitution as not requiring them to do what they are externally constrained from doing successfully, whether some or all of the time, then those rules will occupy the status of law by virtue of their acceptance. ${ }^{122}$

Third, because external constraints will frequently (although not invariably) align with normative constraints in either mandating or precluding the same official acts, mere observation of an official's behavior will often not suffice to prove whether she acted out of a sense of normative obligation, on the one hand, or for instrumental reasons arising from external constraints, on the other. Although I am disposed to believe that many, if not most, officials respond to the pull of normative obligation most of the time, it seems to me a mistake - as I have suggested already - to insist on the categorical priority of one possible source of official motivation over the other.

III

\section{CONSTITUTIONAL CONSTRAINTS ON JUDGES AND JUSTICES}

This Part considers how the constraints identified in Part II apply specifically to judges and especially to justices of the Supreme Court.

\section{A. Normative Constraints}

As noted earlier, several types of evidence-including literature on norms, role theory, and socialization, as well as the personal testimony of judges and

when the Court stood firm for very long against a really clear wave of public demand.”); Steven G. Calabresi, The Tradition of the Written Constitution: Text, Precedent, and Burke, 57 Ala. L. REv. 635, 687 (2006) ("We live in a nation where our Supreme Court follows the presidential and senatorial election returns and frequently overrules major precedents, invoking the constitutional text as its reason for doing so.”). But see Terri Jennings Peretti, In Defense of a Political Court 113-19 (1999) ("[T] consciously chosen by the elected representatives through the selection process."); SEgaL \& Spaeth, Attitudinal Model Revisited, supra note 14, at 424-28 (arguing that Supreme Court decisions generally correspond to public opinion, not because the justices take public opinion into account, but because public opinion influences who is nominated and confirmed to sit on the Court); Whittington, supra note 58, at 73 ("The Court need not regard itself as partisan [when its members have been appointed because their views accord with generally prevailing understandings], for the constitutional understandings shared by those affiliated with the regime will be entrenched and assumed.").

122. See Fallon, supra note 61, at 1140. 
justices ${ }^{123}$ - support the proposition that members of the judicial branch not only experience, but sometimes respond to, normative constitutional constraints. Although much might be said about the probative value of the various forms of evidence, it will be more fruitful to focus on the specific types of normative constitutional constraints plausibly applicable to judges and justices.

\section{Direct Normative Constraints}

Insofar as judges and justices take an internal point of view on legal norms, they are subject to direct normative constraints defined by the Constitution and by surrounding rules of recognition and adjudication (many of which are only tacit). Although the justices are the Constitution's ultimate interpreters for some purposes, they have a duty to follow the law in discharging their functions. H.L.A. Hart described their role in terms that still ring largely true:

At any given moment judges, even those of a supreme court, are parts of a system the rules of which are determinate enough at the centre to supply standards of correct judicial decision. These are regarded by the courts as something which they are not free to disregard in the exercise of the authority to make those decisions which cannot be challenged within the system . . . . The adherence of the judge is required to maintain the standards, but the judge does not make them. ${ }^{124}$

Although most lawyers and ordinary citizens seem likely to assume that judges and even Supreme Court justices are normatively constrained by legal rules, a number of political scientists have challenged that assumption. The most norm-skeptical of the political science accounts, the attitudinal model, postulates that Supreme Court justices consistently vote to decide cases in ways that directly reflect their ideological values. ${ }^{125}$ As Jeffrey Segal and Harold Spaeth pithily summarize their causal theory, "[William] Rehnquist vote[d] the way he [did] because he [was] extremely conservative; [Thurgood] Marshall voted the way he did because he [was] extremely liberal."126

Although the attitudinal model succeeds quite well in predicting the justices' votes, the supporting studies do not seriously undermine the premise that judges and justices are normatively constrained by the Constitution and laws of the United States and that they behave accordingly much of the time. ${ }^{127}$

123. See supra notes $57-58,77-78$ and accompanying text.

124. HART, supra note 17 , at 145-46.

125. See generally sources cited supra note 14. According to Segal \& Spaeth, Attitudinal Model, supra note 4, at 363, the impact of "internal and external non-attitudinal factors ... appears to be minimal."

126. Segal \& Spaeth, Attitudinal Model, supra note 4, at 65.

127. Here, a distinction that Judge Posner draws may be helpful: regardless of whether judges are psychologically, or unconsciously, motivated by ideology, the phenomenology of judging no doubt reveals that judges feel that they are normatively constrained by the 
It is, for example, nearly impossible to imagine a justice who would not experience herself as normatively obliged to enforce the basic free speech rights even of speakers whose views she found politically misguided. ${ }^{128}$ More generally, it is helpful in thinking about direct normative constraints on the justices to distinguish between the typically contentious cases that dominate the Supreme Court's docket and the myriad "easy cases" that never come before any court because their legally correct outcomes would be so uncontestable. ${ }^{129}$ Unanimous opinions provide some evidence that justices of otherwise diverse ideological outlooks acknowledge the existence of rules capable of dictating legally correct outcomes - not chosen on the basis of ideological preferenceswhen those rules clearly apply. ${ }^{130}$ Although the outcomes in clear cases do not by themselves prove that the justices' decisions result from a sense of normative obligation, rather than a response to external constraints, unanimous decisions at least signal the existence of rules of recognition that would generate a sense of obligation among those who take an internal point of view.

A study by Thomas Keck more directly supports the suggestion that the justices normally adopt an internal point of view on constitutional norms. ${ }^{131}$ Based on an examination of the coalitions of justices that invalidated fifty-three federal laws between 1980 and 2004, Keck concludes that more than 70 percent had a bipartisan composition and that "more than [60 percent] . . . [were] inconsistent with a model of policy-motivated judging, either because they were joined by both liberal and conservative justices or because they reached results that are difficult to place in ideological space.”132

In citing evidence that the justices’ ideological preferences cannot always explain their voting, I do not mean to claim that such preferences never have significance. Not all constitutional disputes fall under clearly applicable rules. Indeed, in determining which cases to hear, the Supreme Court attaches a

Constitution. See Posner, supra note 9, at 40 ("Whereas psychology studies primarily the unconscious processes of the human mind, phenomenology studies first-person consciousnessexperience as it presents itself to the conscious mind.”).

128. See id. at 45 (describing judges as having "internalize[d]" the "rules of the judicial 'game'”); Whittington, supra note 58, at 167 (“Judges are supposed to worry about the law, and the individuals selected to be judges are usually socialized into that role.”); Wendel, supra note 55 , at 1485 .

129. See Schauer, Easy Cases, supra note 72, at 408-14.

130. From the Supreme Court's 1994 term through its 2003 term, 35.5 percent of its decisions were by unanimous vote. See Nine Justices, Ten Years: A Statistical Retrospective, 118 HARV. L. REV. 510, 520 tbl.IV (2004).

131. Keck, supra note 40.

132. Id. at 336; see also Rachel E. Barkow, Originalists, Politics, and Criminal Law on the Rehnquist Court, 74 Geo. Wash. L. Rev. 1043, 1045 (2006) (arguing that Rehnquist Court decisions involving Sixth Amendment rights to trial by jury in criminal cases, which often resulted from an alliance between liberal and originalist justices, "provide a concrete and important example of the power of law and legal methodology-and not simply politics-in Supreme Court decision making”). 
priority to addressing issues that have divided lower courts ${ }^{133}$ - presumably because there is no clearly correct resolution on which all reasonable judges could be expected to concur.

Even in the absence of agreement about how a case should be resolved under applicable rules, the possibility exists that justices who take an internal point of view on constitutional norms might perceive themselves as subject to a normative obligation to reach a uniquely correct result. For example, even if there is no widely shared substantive understanding of how to resolve many affirmative action and abortion cases correctly, it does not follow that the justices are at liberty to vote their ideological preferences with no further obligation of fidelity to law. In cases not clearly governed by a widely agreed upon rule or shared tacit understanding, H.L.A. Hart once spoke of judges having "discretion." ${ }^{134}$ In this context, however, the notion of discretion is not self-explanatory. In an early attack on Hart's theory, Ronald Dworkin argued that judges deciding hard cases have a normative obligation to identify the result that best accords with the "principles" reflected in preexisting legal authorities. $^{135}$ In subsequent writings, even some legal positivists have agreed that the American legal system imposes a normative obligation on judges to decide otherwise contestable cases based on judgments concerning which outcome would be legally "best" Dworkin's theory of judges' duties in hard cases. ${ }^{137}$

As suggested above, I believe that a judicial obligation to reach the legally best decision does indeed exist under the tacitly recognized rules of recognition of the American legal system and that Supreme Court justices recognize and try to satisfy that obligation, at least most of the time. ${ }^{138}$ Considerations of moral or practical desirability may sometimes matter legally; the criteria of legality need not exclude normative attractiveness. Nevertheless, I think that the justices are directly normatively constrained to decide cases based only on

133. See Sup. CT. Rule 10 (explaining that the Court considers whether "a United States court of appeals has entered a decision in conflict with the decision of another United States court of appeals on the same important matter" when deciding whether to grant certiorari); see also H.W. Perry, Jr., Deciding to Decide: Agenda Setting in the United States Supreme Court 246-52 (1991) (noting that the Supreme Court often grants certiorari to resolve questions that have divided lower courts).

134. See, e.g., HART, supra note 17, at 127.

135. See DwOrKin, TAKING Rights Seriously, supra note 68, at 24-45.

136. See Himma, supra note 100, at 189-97 (2002) (asserting that the justices are practicing a recognition norm that requires the Court to ground its validity decisions in the best interpretation of the Constitution).

137. See Dworkin, supra note 34, at 398 (asserting that "the American constitution consists in the best available interpretation of American constitutional text and practice as a whole" and maintaining that a judge's "judgment about which interpretation is best is sensitive to the great complexity of political virtues bearing on that issue").

138. See, e.g., Kent Greenawalt, The Rule of Recognition and the Constitution, $85 \mathrm{MicH} . \mathrm{L}$. REv. 621, 662 (1987) ("Judges conceive of themselves as constrained by the law even when no widely accepted social rule imposes such a constraint.”). 
legally pertinent considerations, without regard to personal or partisan interests. $^{139}$

Evidence that much of the public regards the justices as normatively constrained to do their conscientious best to identify legally best outcomes (without regard to extrinsic preferences) emerges from a prominent theme in the critical reaction to Bush v. Gore. ${ }^{140}$ Pointing to some of the justices' perceived deviations from their own interpretive philosophies, ${ }^{141}$ many critics complained of betrayal. ${ }^{142}$ Their protests reflected a deep belief that the justices have a constitutional obligation to strive to identify the outcome that would be legally best, rather than advancing their extralegal political preferences. ${ }^{143}$

If this view of the justices' normative obligations is correct, it generates the initially counterintuitive conclusion-which Professor Dworkin has long pressed-that conscientious justices with partly divergent standards for identifying legally best outcomes in otherwise disputable cases can feel normatively constrained to reach divergent conclusions. ${ }^{144}$ From reasonable and conscientious disagreement, one cannot infer the absence of normative constraint. In the primary, objective sense of that term, the justices may have a legal obligation to do what is legally best, even in the absence of shared substantive criteria for identifying what counts as best. And in the term's phenomenological sense, some justices may apprehend a duty to uphold a claim of constitutional right (in an abortion or affirmative action case, for example), while other justices, who have different criteria for identifying what is best,

139. See CARDozo, supra note 77, at 112 (observing that even when the law is indeterminate, and the judge must function as a legislator, "[t]here must be nothing" in the law or process of judicial decision "that savors of prejudice or favor or even arbitrary whim or fitfulness”).

140. 531 U.S. 98 (2000).

141. In Bush v. Gore, the Supreme Court's most conservative justices, who are usually the least likely to uphold equal protection claims except in affirmative action cases-a potentially revealing signal in itself-all found merit in the equal protection argument asserted by the conservative Republican presidential nominee George W. Bush. Id. at 104-11. See Jack M. Balkin \& Sanford Levinson, Understanding the Constitutional Revolution, 87 VA. L. REv. 1045, 1063 (2001) ("The five conservatives were the least likely ... to extend the Warren Court's equal protection doctrines in the area of voting rights.”). At the same time, the more liberal justices, who typically respond more receptively to equal protection claims, see, for example, Richard L. Hasen, The Untimely Death of Bush v. Gore, 60 Stan. L. Rev. 1, 9 (2007) (noting that liberal judges generally find themselves in "the more familiar position of pushing for an expansion of voting rights through equal protection," while “conservative judges resist[] such expansion”), all dissented in whole or in part. Bush, 531 U.S. at 123-29 (Stevens, J. dissenting); id. at 129-35 (Souter, J., dissenting); id. at 135-44 (Ginsburg, J., dissenting); id. at 144-58 (Breyer, J., dissenting).

142. See, e.g., Vincent Bugliosi, The Betrayal of America (2001); Alan M. Dershowitz, Supreme Injustice (2001); Pamela S. Karlan, Unduly Partial: The Supreme Court and the Fourteenth Amendment in Bush v. Gore, 29 Fla. St. U. L. REv. 587 (2001).

143. See, e.g., Balkin \& Levinson, supra note 141, at 1064-65; Stephen M. Feldman, The Rule of Law or the Rule of Politics? Harmonizing the Internal and External Views of Supreme Court Decision Making, 30 LAw \& Soc. INQuIRY 89, 111-12 (2005).

144. See DwORKIN, supra note 135, at 254-75, 410-13. 
may feel obliged to deny that same claim.

Distinct from the question whether the justices are normatively constrained at all are issues involving the motivational force of normative constraints. In considering these issues, it may prove useful to distinguish between two kinds of cases. One involves a yielding to self-interest or personal preference-what we might think of as weakness of the will or, in a more sinister light, as official corruption. Among the reasons to want normative constraints enforced by external constraints is to diminish the risk of corruption. As I shall discuss below, it is usually taken for granted that external constraints are necessary to enforce nonjudicial officials' adherence to law. I see no good reason to assume that Supreme Court justices, either, would always be wholly efficaciously motivated by purely normative constitutional constraints.

The second, probably rarer question involving the strength of normative constitutional constraints arises when constitutional norms clash with moral norms. Among the difficulties in discussing collisions of legal and moral norms is that people will inevitably disagree about which cases present this problem. I shall therefore limit myself to possible examples. Several of the justices deciding Brown v. Board of Education ${ }^{145}$ at least initially framed their choices as being between what was legally right, on the one hand, and what was morally right, on the other hand. ${ }^{146}$ One could also imagine some of the justices in Bush v. Gore thinking that extralegal policy concerns of supervening importance-possibly involving an impending constitutional crisis if uncertainty over the outcome of the 2000 presidential election persisted significantly longer-called for a conclusion dissonant with their conscientious legal judgment. ${ }^{147}$

In any case of collision between legal and moral norms, moral norms claim superior status. ${ }^{148}$ Moral norms may of course accommodate legal norms to a considerable extent by requiring officials to obey even morally misguided laws, unless the laws are very seriously unjust. ${ }^{149}$ But for an official who takes morality seriously, the question of the force of legal norms will always be a

145. 347 U.S. 483 (1954).

146. See Michael J. Klarman, From Jim Crow to Civil Rights: The Supreme Court and the StrugGle for Racial Equality 292-312 (2004).

147. This is the way that I understand the argument of Richard A. Posner, BREAKING THE Deadlock (2001), though Posner himself seems to believe that his analysis shows the Court's decision to have been legally correct. See Richard H. Fallon, Jr., Legitimacy and the Constitution, 118 HaRv. L. REv. 1787, 1836-37 (2005) (summarizing and characterizing Judge Posner's argument).

148. See, e.g., Bernard Williams, Ethics and the Limits of Philosophy 178 (1985) (explicating "morality" as a variety of ethical thought by noting that "moral obligation is categorical").

149. There is a vast literature on whether, and if so when, there is a moral obligation to obey the law. For an introduction, see William A. Edmundson, State of the Art: The Duty to Obey the Law, 10 Legal THeORY 215 (2004). 
moral question. If we imagine Supreme Court justices as moral saints or heroes, the priority of moral norms over legal norms may provoke scant anxiety. We might think, for example, that even if Brown v. Board of Education was of doubtful correctness as a matter of law, the justices were right, morally speaking, to decide the case as they did and that the country is better as a result. Matters may look different, however, if we imagine the justices to be as prone to moral error as the ordinary lot of humanity. ${ }^{150}$ Adopting that view, we might wish to enforce by external constraints the legal norms that apply to the justices. $^{151}$

\section{Mediated Normative Constraints}

Lower court judges are frequently subject to mediated constitutional constraints, reflecting their obligations to accept the Supreme Court's interpretation of the Constitution even when they believe the Court has erred. ${ }^{152}$ Judges who fail to respect this obligation often draw criticism for being lawless $^{153}$ — a form of external constraint that I shall discuss below.

Supreme Court justices, too, are subject to mediated normative constraints, including prior Court precedents. After discussing the role of precedent in Supreme Court decision-making, I shall briefly examine a few additional sources of mediated normative constraints on the Court. A review indicates that although mediated constraints seldom bind the justices categorically, such constraints exist, and the justices' stance toward them helps

150. See, e.g., Jeremy Waldron, Moral Truth and Judicial Review, 43 Aм. J. JuRIs. 75, 88 (1998) (arguing that we lack any "epistemic apparatus that would enable us to ground any but the most trivial and unhelpful inductions about expertise and institutional competence"); see also Richard A. Posner, The Problematics of Moral and Legal Theory, 111 Harv. L. Rev. 1637 (1998).

151. See Frederick F. Schauer, Playing by the Rules: A Philosophical Examination of Rule-Based Decision-Making in LaW and in Life 158-66 (1991) (explaining the function of rules in allocating power).

152. See, e.g., Weber v. Kaiser Aluminum \& Chem. Corp., 611 F.2d 132, 133 (5th Cir. 1980) (complying with a Supreme Court order to vacate a judgment despite believing that order to be "profoundly wrong" because "[s]ubordinate magistrates . . . must either obey the orders of higher authority or yield up their posts to those who will”); Hammond v. Bostic, 368 F. Supp. 732, 736 (W.D.N.C. 1974) (reversing an earlier grant of a writ of habeas corpus in light of a supervening Supreme Court opinion, despite the judge's admission that he "agree[d] thoroughly with the Supreme Court dissenters rather than with the majority"). For a prominent discussion of hierarchical precedent, see Evan H. Caminker, Why Must Inferior Courts Obey Superior Court Precedents?, 46 Stan. L. Rev. 817 (1994).

153. A recent example involves Roy Moore, former chief justice of the Alabama Supreme Court, who was removed from office by a judicial ethics panel after he defied a federal court order to remove a monument of the Ten Commandments from the state judicial building. See Jeffrey Gettleman, Alabama Panel Ousts Judge Over Ten Commandments, N.Y. Times, Nov. 14, 2003, at A16. In another example, several Ninth Circuit judges drew criticism for what seemed to many to be their refusal to follow Supreme Court precedent when they repeatedly granted stays as California attempted to execute Robert Alton Harris. See Caminker, supra note 152, at 819 \& n.6 (describing how "[m]any observers denounced the Ninth Circuit judges for defying the Supreme Court's pronouncements”); Fried, supra note 110. 
illuminate their understandings of the Court's role.

\section{a. Constraint by Precedent}

The mediated constraint that the justices most commonly acknowledge involves the doctrine of stare decisis. ${ }^{154}$ Absent good reason not to do so, the justices consider themselves bound by previous Supreme Court decisions. ${ }^{155} \mathrm{By}$ the justices' own account, the normative constraint arising from precedent is not absolute. The Court has said frequently that stare decisis is a principle of policy, not an inexorable constitutional command. ${ }^{156}$ As I have noted, however, a constraint need not be absolute in order to count as a constraint.

A more serious question about the normatively constraining effect of precedent comes from attitudinalist political scientists. According to them, precedent has little if any weight in the Supreme Court. ${ }^{157}$ Indeed, Professors Segal and Spaeth have concluded that although the justices pay lip service to precedent, only rarely do they deviate from their revealed ideological preferences by acknowledging that a disputed case is controlled by a landmark precedent from which they dissented. ${ }^{158}$

Segal and Spaeth's data prove less than the authors claim. ${ }^{159}$ In thinking about the effects of precedent on the Supreme Court, I would begin not with the justices' votes in disputed cases, but instead with the phenomenon that nearly everyone regards some constitutional issues that once provoked sharp debate as having been resolved conclusively by prior decisions. ${ }^{160}$ For example, the

154. See, e.g., Dickerson v. United States, 530 U.S. 428, 443 (2000) (describing how "the principles of stare decisis weigh heavily against overruling [the rule established in Miranda $v$. Arizona, 396 U.S. 868 (1969)] now," even if the Court would not agree with Miranda's reasoning or holding in the first instance).

155. See, e.g., id. (explaining that stare decisis "carries such persuasive force that we have always required a departure from precedent to be supported by some 'special justification'” (quoting United States v. IBM Corp., 517 U.S. 843, 856 (1996)).

156. See, e.g., Seminole Tribe of Fla. v. Florida, 517 U.S. 44, 63 (1996) (“[W]e always have treated stare decisis as a 'principle of policy,' (quoting Helvering v. Hallock, 309 U.S. 106, 119 (1940), and not as an 'inexorable command,' (quoting Payne v. Tennessee, 501 U.S. 808, 828 (1991).”).

157. See Spaeth \& Segal, Adherence to Precedent, supra note 14, at 287 (asserting that "precedent rarely influences United States Supreme Court justices").

158. See, e.g., Segal \& Spaeth, Attitudinal Model Revisited, supra note 14, at 298310; Spaeth \& Segal, Adherence to Precedent, supra note 14, at 287-315; see also Youngsik Lim, An Empirical Analysis of Supreme Court Justices' Decision Making, 29 J. LegaL STUD. 721, 739 (2000) ("Regardless of whether or not she was a member of the majority in the precedent, a justice would strongly tend to follow her decision rather than the precedent itself.”).

159. Studies by other political scientists have suggested that precedent has a more significant effect than Segal and Spaeth allow, even in the disputed Supreme Court cases on which they focus. See Saul Brenner \& Marc Stier, Retesting Segal \& Spaeth's Stare Decisis Model, 40 AM. J. Pol. ScI. 1036, 1043 (1996) (finding that in 47 percent of subsequent cases, "four center justices" included in the Segal and Spaeth study joined the main precedent-following opinion without attempting to distinguish or overrule it).

160. See Mark A. Graber, Looking off the Ball: Constitutional Law and American Politics, (Univ. of Md. Sch. of Law Legal Studies, Research Paper No. 2007-24), available at 
justices are unanimous in viewing precedent as establishing that paper money is constitutional; ${ }^{161}$ that the Equal Protection Clause bars race-based discrimination in public schools ${ }^{162}$ and imposes one-person, one-vote requirements; ${ }^{163}$ that the Fourteenth Amendment incorporates most of the guarantees of the Bill of Rights against the states; ${ }^{164}$ that the federal government is bound by equal protection principles even though the Equal Protection Clause applies formally only to the states; ${ }^{165}$ that the Constitution permits the vesting of broad regulatory and adjudicative powers in administrative agencies; ${ }^{166}$ and that a multitude of important federal regulatory statutes, including the 1964 Civil Rights Act, ${ }^{167}$ were validly enacted under the Commerce Clause.

Although not all precedents bind absolutely, the nearly pervasive sense that past judicial decisions have conclusively resolved some issues helps confirm the existence of what I have referred to as "tacit" rules of constitutional adjudication. ${ }^{168}$ A broadly shared understanding exists that a decision to overturn some precedents-especially those the overruling of which would cause large practical dislocations-would exceed the outer limits of lawful judicial power, even if an otherwise attractive normative constitutional theory might mandate the overruling. ${ }^{169}$

If one assumes that the authority of at least some precedents reflects tacit and broadly shared understandings of what the law requires, disputes about whether the Court should overrule controversial decisions such as Roe $v$.

http://ssrn.com/abstract=1006032.

161. See Legal Tender Cases, 79 U.S. 457, 547 (1870), rev'g Hepburn v. Griswold, 75 U.S. 603 (1870).

162. See Brown v. Bd. of Educ., 347 U.S. 483 (1954).

163. See, e.g., Reynolds v. Sims, 377 U.S. 533 (1964).

164. See, e.g., Duncan v. Lousiana, 391 U.S. 145 (1968).

165. See, e.g., Adarand Constructors, Inc. v. Pena, 515 U.S. 200 (1995).

166. See, e.g., Crowell v. Benson, 285 U.S. 22 (1932).

167. See, e.g., Katzenbach v. McClung, 379 U.S. 294 (1964).

168. See Fallon, supra note 61, at 1129-36.

169. See id. at 1149 (arguing that precedents are invulnerable to overruling when they "have established a rule of law around which strongly held, settled expectations or reliance interests have developed" and "deal[] with matters that no longer occasion broad, ongoing, unstable contestation in American law and politics”). Such prominent originalists as Judge Robert Bork and Justice Antonin Scalia, who normally demand that judicial decisions reflect the original understanding of constitutional language, have thus said that they would make an exception for cases governed by deeply entrenched precedent. See Robert H. Bork, The Tempting of America: The Political Seduction of the Law 155 (1991) ("Whatever might have been the proper ruling shortly after the Civil War, if a judge today were to decide that paper money is unconstitutional, we would think he ought to be accompanied not by a law clerk but by a guardian.”); Antonin Scalia, A Matter of Interpretation: Federal Courts and the LaW 138-40 (Amy Gutmann ed., 1997) (characterizing respect for precedent as an exception to his originalist theory, not as an aspect of it); see also JefFrey Toobin, The Nine: Inside the Secret World of THE Supreme Court 103 (2007) (quoting Justice Scalia as comparing his own judicial philosophy with that of Justice Clarence Thomas by observing that "I am an originalist, but I am not a nut”). 
Wade $^{170}$ and about whether particular precedents control current cases (or are somehow distinguishable) are predictable examples of reasonable disagreement within our constitutional practice. They demonstrate only the limits, not the absence, of constraint by precedent-though, in gauging those limits, one should recognize that officials' phenomenological sense of constraint may sometimes deviate from what "the law" would actually require. In other words, although officials' psychological sense of constraint is important, particular officials' beliefs about their obligations do not necessarily reflect what the Constitution in fact requires them to do. ${ }^{171}$

\section{b. Additional Mediated Normative Constraints}

The Supreme Court regularly professes that it is subject to mediated constitutional constraints besides precedent, but, as a few examples will demonstrate, its position is wary and ambivalent. The Court may have good reason for refusing to formulate and adhere to clear, rule-like statements of the mediated normative constraints on its power to determine "what the law is." 172

The political question doctrine. The political question doctrine obliges the Supreme Court to treat other branches' determinations of some constitutional questions as controlling. ${ }^{173}$ In other words, determinations by the political branches in political question cases constrain the courts from reaching any other conclusion. Strikingly, however, although almost everyone acknowledges that there is a political question doctrine, ${ }^{174}$ Supreme Court practice has left the doctrine so badly defined that no consensus exists as to what exactly the doctrine is or when it applies. ${ }^{175}$

Deferential standards of review. Some judicial doctrines call for courts, including the Supreme Court, to uphold the constitutionality of challenged legislation or executive action as long as it satisfies a minimal standard of reasonableness. ${ }^{176}$ On one interpretation of such doctrines, the Court regards

170. 410 U.S. 113 (1973).

171. Cf. Simon, supra note 33, at 1129 (offering a cognitive psychological explanation of how Supreme Court justices on opposite sides of a disputable case can all believe that they are constrained by the law to arrive at the conclusions that they reach).

172. Marbury v. Madison, 5 U.S. (1 Cranch) 137, 177 (1803).

173. See, e.g., Nixon v. United States, 506 U.S. 224 (1993).

174. But cf. Louis Henkin, Is There a "Political Question" Doctrine?, 85 YALE L.J. 597, 622-23 (1976) (arguing that the so-called political question doctrine is "an unnecessary, deceptive packaging of several [independently] established doctrines" and has no further, legally valid scope).

175. See generally Richard H. Fallon, Jr., et al., Hart \& Wechsler's The Federal Courts and the Federal System 244-67 (5th ed. 2003) (reviewing the range of positions taken in leading political question cases and the surrounding scholarly literature).

176. See, e.g., FCC v. Beach Commc’ns, Inc., 508 U.S. 307, 313-15 (1993) (affirming that statutes subject to rational basis review will be upheld "if there is any reasonably conceivable state of facts that could provide a rational basis for the classification"); McGowan v. Maryland, 366 U.S. 420, 425-46 (1961) (stating that "[t]he constitutional safeguard is offended only if the classification rests on grounds wholly irrelevant to the achievement of the State's objective” and 
itself as normatively constrained to accept any reasonable judgment by the other branch about what the Constitution permits or requires. ${ }^{177}$ On another interpretation, however, highly deferential doctrines do not assume the Court is bound by other branches' determinations of constitutionality. They instead embody conclusions that the Court, typically for reasons involving institutional competence, should not enforce the Constitution to its "full conceptual limits."178

Long unchallenged executive practice. The Supreme Court has sometimes said that long unchallenged executive practice, if acquiesced in by Congress, can constrain it from making rulings of unconstitutionality that it otherwise might make. ${ }^{179}$ Significantly, however, the Court has carefully hedged its formulations to leave considerable uncertainty about when it will regard itself as bound in this way. ${ }^{180}$

Constitutional theories. Many normative constitutional theories call upon the justices to accept someone else's understanding of what the Constitution means. Originalism would thus require the Court to regard the intent or understanding of the founding generation as controlling, even if the justices would otherwise understand their constitutional obligations differently. ${ }^{181}$ Common law theories call for judges to accord authority to prior judges' and justices' interpretations of constitutional language. ${ }^{182}$ To give just one more example, James Bradley Thayer's theory, under which the Court should uphold legislation unless it reflects a "clear mistake" about constitutional meaning,

that "[a] statutory discrimination will not be set aside if any state of facts reasonably may be conceived to justify it”); see also Lawrence Gene Sager, Fair Measure: The Legal Status of Underenforced Constitutional Norms, 91 Harv. L. Rev. 1212, 1215 \& n.6, 1234 \& n.76 (1978) (citing McGowan and explaining that "[u]nder the rational relationship test as it is normally applied, only an utterly bizarre and capricious state legislative act will be held unconstitutional”).

177. See, e.g., District of Columbia v. Heller, 128 S. Ct. 2783, 2817 n.27 (2008) (asserting that "'rational basis' is not just the standard of scrutiny, but the very substance of the constitutional guarantee”).

178. See Sager, supra note 176, at 1235; see also Lawrence G. Sager, Justice IN Plainclothes: A Theory of American Constitutional Practice (2004).

179. See, e.g., Medellin v. Texas, 128 S. Ct. 1346, 1371 (2008) (acknowledging that "if pervasive enough, a history of congressional acquiescence can be treated as 'a gloss on "Executive Power” vested in the President by § 1 of Art. II’”) (quoting Dames \& Moore v. Regan, 453 U.S. 654, 686 (1981)).

180. Cf. Medellin, 128 S. Ct. at 1370 (“[E]ven if we were persuaded that congressional acquiescence could support the President's asserted authority to create domestic law pursuant to a non-self-executing treaty, such acquiescence does not exist here.”).

181. See Bork, supra note 169, at 143-60 (arguing that "[w] in the Constitution as originally understood," he is bound by that principle and "[h]e need not, and must not, make unguided value judgments of his own”); Antonin Scalia, Originalism: The Lesser Evil, 57 U. CIN. L. REv. 849, 852 (1989) (distinguishing between opinions "rendered . . . on the basis of what the Constitution originally meant," and those rendered "on the basis of what the judges currently thought it desirable for it to mean”).

182. See generally David A. Strauss, Common Law Constitutional Interpretation, 63 U. CHI. L. REv. 877, 883 (1996) (defending an approach to constitutional interpretation under which "[m]ostly the courts decide cases by looking to what the precedents say"). 
would require the justices to extend authoritative status to the judgments of the legislature in nearly all cases. ${ }^{183}$

Constitutional theories hold endless interest for law professors. Interestingly, however, the justices themselves appear less preoccupied with constitutional theory as they go about their workaday business of resolving constitutional controversies. Although methodological disputes grow heated in some cases, it is striking that in the domain of constitutional adjudication, the justices have seldom exhibited much interest in attempting to bind either themselves or each other, in advance, to the kind of general interpretive approaches that academic theorists champion. ${ }^{184}$

If one asks why, two plausible explanations spring to mind. First, the justices might simply prefer to maximize the scope of their decision-making latitude. ${ }^{185}$ But this explanation is not wholly satisfactory. If a majority of the justices shared an interpretive philosophy, they might actually maximize their power if they could bind other justices to adopt their methodology.

Second, and more interestingly, the justices might believe that although they are bound by tacit norms of constitutional adjudication, their tacit knowledge defies accurate expression in propositional form. ${ }^{186}$ Specifically, the justices might believe that although one or another constitutional theory comes closest to describing accurately the normative constraints to which they are subject, none does so perfectly, and that the tacit norms of constitutional adjudication thus actually constrain them from adopting any theory that might

183. See James B. Thayer, The Origin and Scope of the American Doctrine of Constitutional Law, 7 Harv. L. REv. 129, 144 (1893) (urging courts to invalidate statutes only when Congress has made a "very clear" mistake); see also AdRIAN Vermeule, JudGing Under UnCERTAinty: An Institutional Theory of Legal Interpretation 270-76 (2006) (endorsing "a more specific interpretation or conception of" Thayer's approach, under which "courts would be limited to enforcing, through judicial review, only clear and specific constitutional texts - the sort of texts that Marshall used as examples of judicial review in Marbury itself").

184. See Cass R. Sunstein, Incompletely Theorized Agreements, 108 Harv. L. Rev. 1733, 1735-36 (1995) (arguing that judges in "well-functioning legal systems" frequently agree only on "the result and on relatively narrow or low-level explanations for it" without needing to "agree on fundamental principle" or "offer larger or more abstract explanations than are necessary to decide the case"); see also Cass R. Sunstein, One Case at a Time: Judicial Minimalism on the Supreme Court (1999). There are some who argue that, contrary to current practice, courts should give interpretive methodologies stare decisis effect in a way that would bind the justices to theory. See Sydney Foster, Should Courts Give Stare Decisis Effect to Statutory Interpretation Methodology, 96 Geo. L.J. 1863 (2008).

185. See Mark V. Tushnet, The New Constitutional Order 140 (2003) (noting that the "minimalism" under which justices eschew general commitments maximizes their flexibility); Alexander Volokh, Choosing Interpretive Methods: A Positive Theory of Judges and Everyone Else, 83 N.Y.U. L. Rev. 769 (2008) (arguing that it is rational for judges to adjust their methods from case to case to reach appealing outcomes).

186. Benjamin Cardozo thus spoke of judges as being subject to "restrictions not easy to define, but felt." Cardozo, supra note 77, at 114. See generally GiLbert Ryle, The ConCEPT OF Mind 27-32 (1949) (emphasizing the importance of the distinction between "knowing how" and "knowing that"). 
diverge from those tacit norms in possibly unforeseeable future cases. For example, a justice might believe that tacit, governing norms require her to reach originalist decisions in some cases, to exercise Thayerian restraint in others, and to follow non-originalist precedent that is incompatible with Thayerian restraint in resolving other disputes. When the justices appear methodologically inconsistent, theorists object that the inconsistency shows intellectual bankruptcy and press the normative case for their preferred approaches with renewed urgency. It is possible, however, that many normative theorists have misapprehended the relationship between constitutional theory and constitutional practice. Whereas normative theorists often assume that an important role of theory is to improve constitutional practice, the justices may believe that constitutional theory could at most describe the tacit norms of existing practice and could have little or no authority to transform them.

\section{Constitutionally Authorized Normative Constraints}

As much as other officials, judges and justices are normatively constrained by validly enacted law, including statutes that regulate their jurisdictions. ${ }^{187}$ Statutory constraints on judges and justices have enormous importance. It is nearly impossible to imagine a justice who would not feel constrained to enforce any law enacted by Congress, despite her personal disapproval of it, unless she had a good legal reason to hold it unconstitutional. A recent example comes from statutes specifying penalties for criminal offenses that some judges have regarded as draconian. ${ }^{188}$ The justices appear

187. Because Article III of the Constitution does not require Congress to create any lower federal courts at all, U.S. ConST. art. III, § 1, lower federal courts possess jurisdiction only insofar as jurisdiction is conferred by statute. See FALLON ET AL., supra note 175, at 330-37. Although Article III expressly confers both original and appellate jurisdiction on the Supreme Court, the appellate jurisdiction is subject to "such Exceptions . . . as the Congress shall make.” U.S. Const. art. III, § 2, cl. 2. With Congress having regulated the Court's appellate jurisdiction since the 1789 Judiciary Act, the Court's current appellate jurisdiction is almost entirely governed by statute. See 28 U.S.C. §§ 1251-59 (2006). Although it is almost universally agreed that some possible statutory limitations on the Court's jurisdiction would violate the Constitution, see FALLON ET AL., supra note 175, at 334-35, 337, the bounds on congressional power have seldom been tested and remain much debated. See id. at 337-42.

188. A number of judges have criticized statutes that establish mandatory minimum sentences - including life sentences without the possibility for parole - for drug offenses. See, e.g., John Caher, Judge Gives 'Small-Time' Dealer 'Unjust' Mandatory Life, LEGAL InTELligencer, Jan. 20, 2006, at 4. When Northern District of New York Judge David N. Hurd was forced under 21 U.S.C. § 846 to impose a life sentence on a "relatively small-time drug dealer," he remarked: "The increment of harm in this case bears no rational relationship to the increment of punishment that I must impose. This is what occurs when Congress sets [a] mandatory minimum sentence which distorts the entire judicial process.” Id. (quoting Judge Hurd). In United States v. Booker, 543 U.S. 220, 226-27 (2005), the Court held that any factual predicate for the imposition of a sentence comes within the province of the constitutional right to trial by jury, but it did not question that Congress may prescribe mandatory penalties for crimes as statutorily defined, which the Court had earlier held constitutional in McMillan v. Pennsylvania, 477 U.S. 79 (1986), and Harris v. United States, 536 U.S. 545 (2002). 
never to have doubted that they and other judges must enforce all statutorily mandated penalties that are not substantively unconstitutional.

To be sure, statutes often require interpretation, and the justices frequently divide along ideological lines in contested statutory cases (just as they do in constitutional disputes). Again, however, one should not view cases that provoke divisions as evidence of the absence of constraints. Judges and justices who take an internal point of view will experience themselves as normatively constrained to follow constitutionally valid statutes whenever they conclude (under accepted rules of statutory interpretation) that those statutes apply.

\section{B. External Constraints}

\section{Inefficacy or Nullity Under Applicable Rules of Recognition}

Judges and justices are constrained by the prospect that some decisions they might imaginably render would be treated as nullities or otherwise prove inefficacious. ${ }^{189}$ While some rules of recognition tell justices how to identify valid law, others, applicable to other officials, characteristically direct those other officials to accept judicial interpretations as binding-even when those other officials think the judges made mistakes. ${ }^{190}$ But there are limits. For example, as I have said before, a judicial directive purporting to raise or lower interest rates solely for policy reasons would not be recognized as legally authoritative. $^{191}$

This conclusion may appear trivial, but I do not believe that it is. As Fred Schauer has documented, the Supreme Court's docket typically includes few of the issues that most American regard as most pressing. ${ }^{192}$ Matters of war and peace, economic boom and bust, and priorities in the provision of public services seldom come within the province of judicial decision-making. In light of familiar assumptions that unchecked power tends to expand, ${ }^{193}$ we might ask why this is so. Part of the answer lies in the justices' awareness of external constraints.

189. See, e.g., Himma, supra note 100, at 154; McNollgast, supra note 12, at 1641-47.

190. See, e.g., Hutto v. Davis, 454 U.S. 370, 375 (1982) (per curiam) (“[U]nless we wish anarchy to prevail within the federal judicial system, a precedent of this Court must be followed by the lower federal courts no matter how misguided the judges of those courts may think it to be.”); Cooper v. Aaron, 358 U.S. 1, 18-19 (1958) (explaining that “[n]o state legislator or executive or judicial officer can war against the Constitution without violating his undertaking to support it," and that all officials are thereby bound by the Supreme Court's constitutional interpretations); see also Alexander \& Schauer, Extrajudicial Interpretation, supra note 97, at 1362 (offering an unqualified defense of Cooper “and its assertion of judicial primacy”).

191. Cf. William Baude, The Judgment Power, 96 GEo. L.J. 1807, 1862 (2008) (arguing that the judicial power to bind the president applies only when a court is acting within its jurisdiction).

192. See Schauer, supra note 50.

193. But $c f$. Levinson, supra note 46 (challenging the premise that government officials characteristically seek to expand the power of the institutions in which they serve). 
As a historical matter, the prospect of judicial pronouncements being treated as nullities or otherwise proving inefficacious is hardly hypothetical. ${ }^{194}$ President Thomas Jefferson and Secretary of State James Madison credibly threatened to defy the Supreme Court if it awarded mandamus relief to William Marbury in Marbury v. Madison. ${ }^{195}$ Abraham Lincoln directed his subordinates to ignore the ruling of Chief Justice Taney in Ex parte Merryman. ${ }^{196}$

Another example may come from the World War II case of Ex parte Quirin, ${ }^{197}$ in which the Court upheld executive authority to try alleged Nazi saboteurs before military tribunals rather than civilian courts. ${ }^{198}$ While the case was pending, President Franklin D. Roosevelt made it known to the justices that if they ruled for the petitioners, he would order military trials and summary executions to proceed anyway. ${ }^{199}$ In the wartime circumstances, military personnel would almost certainly have obeyed presidential orders to ignore a judicial ruling - a consideration that may well have affected the Court's decision to uphold the constitutionality of military trials. ${ }^{200}$ The Court may also have framed its famous order that local schools boards should enforce the rights recognized in Brown v. Board of Education" ${ }^{201}$ "with all deliberate speed,"202 rather than posthaste, partly because it knew that a mandate of immediate desegregation might have proved inefficacious. ${ }^{203}$

194. See WhitTington, supra note 58, at 31-40 (summarizing well-known episodes of actual and threatened presidential defiance of judicial authority).

195. 5 U.S. (1 Cranch) 137 (1803). For a discussion of the political context surrounding Marbury and the possibility that the Supreme Court's mandate would have been defied had the Court reached a different result, see Bruce A. Ackerman, The Failure of the Founding Fathers: Jefferson, Marshall, and the Rise of Presidential Democracy 182-86 (2005); see also Richard H. Fallon, Jr., Marbury and the Constitutional Mind: A Bicentennial Essay on the Wages of Doctrinal Tension, 91 CALIF. L. Rev. 1, 16-20, 27-33 (2003) (describing Marbury as a prudent response to the nation's political context and discussing the continuing existence of prudential decision making).

196. 17 F. Cas. 144 (C.C.D. Md. 1861). For a detailed analysis of the decision in Ex parte Merryman and its aftermath, see DANiel A. FARber, LinCOLN's Constitution 17, 157-63, 18895 (2003).

197. 317 U.S. 1 (1942).

198. Id. at 48 .

199. See Daniel J. Danelski, The Saboteur's Case, 1996 J. Sup. Cт. Hist. 61, 69.

200. In what Justice Scalia has subsequently termed "not this Court's finest hour," Hamdi v. Rumsfeld, 542 U.S. 507, 569 (2004) (Scalia, J., dissenting), the justices announced their ruling in Quirin almost immediately after the argument in the case, with the opinion explaining their reasoning issuing months later, after the petitioners had already been tried and executed by the military. See Richard H. Fallon, Jr. \& Daniel J. Meltzer, Habeas Corpus Jurisdiction, Substantive Rights, and the War on Terror, 120 HARv. L. Rev. 2029, 2078-79 (2007).

201. 347 U.S. 483 (1954).

202. Brown v. Bd. of Educ. (II), 349 U.S. 294, 301 (1955).

203. See Klarman, supra note 146, at 312-20. In an example that is both more mundane and potentially more far-reaching, some political scientists believe that the Supreme Court frequently renders rulings that it regards as less than "ideal" in order to promulgate rules of decision by which it can expect lower courts and other official actors actually to abide. See McNollgast, Conditions for Judicial Independence, 15 J. ConTEMP. Legal Issues 105, 112-19 (2006). Because the Court can hear only a limited number of cases, it cannot effectively enforce 
Without attempting to account systematically for all possible external constraints that arise from the prospect that judicial rulings might be null under the rules of recognition practiced by nonjudicial officials, or might otherwise provoke defiance, I offer three observations.

First, in cases in which the justices worry that executive officials or lower courts might defy their rulings, they may feel a tension between the direct normative constraints and the external constraints to which they are subject. In other words, they may believe that they have a legal duty to do what they may feel externally constrained from doing. In Quirin, for example, the justices might easily have believed that at least one of the alleged saboteurs - a U.S. citizen who had been apprehended within the United States-had a constitutional right to civilian trial. ${ }^{204}$

As I noted above, however, it also seems plausible that in a case such as Quirin, external constraints might affect the justices' perceptions of their legal duties. For example, in reflecting upon precedents such as Marbury $v$. Madison $^{205}$ and Stuart v. Laird, ${ }^{206}$ in which the Court bowed to political threats, the justices may have concluded that the "rule of recognition" authorizes them to avoid rulings that would likely provoke broadly supported defiance and thereby threaten the long- or short-term authority of the judicial branch. As I have written elsewhere:

Looking at the Supreme Court's long-term pattern of decisions, I would surmise that the Justices have internalized the constraint that the Court must conduct itself in ways that the public will accept as lawful and practically tolerable . . . : the Court's interpretations of the Constitution must be likely to be accepted and enforced by at least a critical mass of the officials normally counted on to implement judicial decisions, and they should not trigger a strong and enduring sense of mass outrage by political majorities that the Court has overstepped its constitutional powers. $^{207}$

doctrinal rules that the lower courts will not strive conscientiously to implement. See id. at 119; see also Friedman, supra note 10, at 295-308 (discussing the effect of the need to secure compliance from lower court judges on Supreme Court decision-making). Accordingly, these political scientists reason, the Court cannot achieve the results that it wishes unless it sufficiently accommodates the views of the lower federal judiciary to get them to play the role of faithful agents. See McNollgast, Conditions for Judicial Independence, supra, at 112-19. In advancing this analysis, the authors who write jointly as McNollgast assume that judicial "[d]octrine emerges as part of the equilibrium interaction among the Supreme Court and the lower courts," with no actor responding to normative constraints and "each acting to maximize its own preferences or ideology." McNollgast, supra note 12, at 1646. Although I resist here as elsewhere the premise that all judges and justices behave in this way all of the time, I accept that some might do so at least some of the time and take seriously the suggestion that judges and justices may take note of, and sometimes respond to, external constraints on their de facto authority.

204. See Fallon \& Meltzer, supra note 200, at 2078-80.

205. 5 U.S. (1 Cranch) 137 (1803).

206. 5 U.S. (1 Cranch) 299 (1803).

207. Fallon, supra note 61, at 1140. 
Second, while assent to judicial mandates is today the norm, and official defiance of court rulings the exception, some observers believe that nonjudicial officials should feel freer than they presently do to treat judicial rulings as not binding on them. In a much discussed book, Larry Kramer has argued that nonjudicial officials once regarded themselves as being entitled as judges to interpret the Constitution, even after the courts had spoken, and to treat judicial rulings as limited to the particular cases in which they were issued or even to ignore them. ${ }^{208}$ Whatever historical practice may have been, the recognition practices of nonjudicial officials could change in the future, with official defiance of judicial rulings becoming more common. ${ }^{209}$ The external constraints on judges and justices are thus potential variables.

Third, if we ask why elected officials, in particular, currently accede so readily to claims of judicial authority that are not clearly ultra vires, part of the answer can be traced to the external constraint that public expectations impose. The public expects governmental officials to obey the law, and the public has been socialized to believe that judicial interpretations are legally binding. ${ }^{210}$ But reference to current norms only postpones the question of how a state of affairs developed in which judicial authority to resolve disputable constitutional questions is so widely accepted.

In addressing this question, it is just as important to recognize that the domain of recognized judicial authority is bounded - that there are some issues committed almost wholly to resolution by politically accountable officials-as it is to note that judicial authority is seldom seriously questioned within its sphere. In accounting for these phenomena, political scientists increasingly argue that the domain within which the Court possesses recognized authority is politically "constructed."211 With respect to the kinds of issues concerning which the courts speak authoritatively, elected officials prefer that the courts do speak authoritatively. ${ }^{212}$ Maintenance of a relatively independent judiciary within a limited sphere may be the preferred strategy of risk-averse political leaders who willingly forego some opportunities to exercise power while they

208. See Larry D. Kramer, The People Themselves: Popular Constitutionalism and Judicial Review (2005). The book has attracted vigorous criticism. See, e.g., Larry Alexander \& Lawrence B. Solum, Popular? Constitutionalism?, 118 Harv. L. Rev. 1594 (2005) (book review).

209. See generally Whittington, supra note 58 (exploring the historical conditions tending to support "judicial supremacy" in constitutional interpretation and emphasizing their contingency).

210. See Fallon, supra note 107, at 23.

211. See, e.g., Whittington, supra note 58, at 4; Mark A. Graber, Constructing Judicial Review, 8 Ann. Rev. Pol. Sci. 425 (2005).

212. See Whittington, supra note 58, at 25 ("As it has become evident that judicial supremacy is more often a help than a hindrance to political leaders, judicial supremacy has become more prominent and secure.”). See generally RAN HIRSCHL, TOWARDS JuRISTOCRACY: The Origins and Consequences of the New Constitutionalism (2004) (describing conditions under which vulnerable political elites in other nations have chosen to establish robust schemes of judicial review to protect the then-prevailing elite's values). 
hold office in order to prevent unbounded power by their political adversaries when the adversaries triumph at the polls. ${ }^{213}$ Perhaps of even greater significance, politicians may find it to their electoral advantage to leave a range of contentious issues for judicial resolution. ${ }^{214}$ Congress and the president may also be happy to see dominant national visions enforced against the states ${ }^{215}$ and to delegate to the courts a number of issues possessing low political salience. $^{216}$

If political scientists are correct that the domain of judicial authority is politically constructed, however, there is no guarantee that the political forces that define that domain will remain in long-term equilibrium. From the perspective of some political scientists, every election is a potential external shock to the system. ${ }^{217}$ Keith Whittington advances the more architectonic thesis that, from time to time, "reconstructive" presidents have confronted the Supreme Court, sometimes successfully, and have forced a redefinition of the substantive bounds within which acceptable judicial decision-making can occur. $^{218}$ According to Professor Whittington, Thomas Jefferson, Andrew Jackson, Abraham Lincoln, and Franklin Roosevelt all achieved this effect to greater or lesser degrees. ${ }^{219}$ They did so partly by persuading the public to accept their visions of constitutional meaning and partly, having prevailed in the court of public opinion, by appointing justices who shared their constitutional visions. Thus, to take the starkest example, the prevailing constitutional understandings that emerged from the Roosevelt Revolution of the 1930s - in the country as well as on the Court— differed vastly from those of the 1920s, and the principal engine driving the change was Franklin Roosevelt. $^{220}$

213. See Matthew C. Stephenson, "When the Devil Turns ... " ": The Political Foundations of Independent Judicial Review, 32 J. LeGAL STUD. 59 (2003).

214. See, e.g., Whittington, supra note 58, at 134-52; Mark Graber, The Nonmajoritarian Difficulty: Legislative Deference to the Judiciary, 7 Stud. Am. Pol. Dev. 35, 38 (1993) ("When disputes arise that most elected officials would rather not address publicly, Supreme Court justices may serve the interests of the political status quo by making policy favored by political elites."); Keck, supra note 40, at 327-28 (noting that the Court decisions invalidating federal statutes on federalism grounds "allow Republican legislators to posture for their constituents by enacting popular civil rights statues... while pursuing their broader ideological agenda of limited government through the courts").

215. WhitTington, supra note 58, at 105-20.

216. See id. at 120-24.

217. See McNollgast, supra note 12, at 1655-56; see also Balkin \& Levinson, supra note 141, at 1102 (advancing a "theory of partisan entrenchment" under which "each party has the political 'right' to entrench its vision of the Constitution in the judiciary if it wins a sufficient number of elections").

218. See, e.g., Whittington, supra note 58, at 22-23 (discussing the capacity of "reconstructive" presidents to construct "a new political regime" with altered "constitutional and ideological norms").

219. See id. at 31-40.

220. See, e.g., Larry D. Kramer, The Supreme Court, 2000 Term-Foreword: We the Court, 115 Harv. L. Rev. 5, 120-28 (2001) (describing "the New Deal settlement” that replaced 
In order for external constraints to be effective, judges and justices need not respond to them self-consciously, "for the constitutional understandings shared by those affiliated" with the dominant political coalition or "regime"including jurists who have been nominated and confirmed with their constitutional visions in mind- "will be entrenched and assumed.",21 Nevertheless, the external constraints that define the domain of politically acceptable judicial action can exert important influence as parts of the process through which current and future judges identify and internalize legal norms. As Thomas Keck puts it, “The justices' ostensibly political preferences have themselves been constituted in part by legal ideas, and those legal ideas, in turn, have been derived in large part from ongoing debates in the broader political system."222

\section{Concurrent Agreement or Acquiescence Requirements}

The Supreme Court "is a they, not an it."223 In considering constraints on the Court as an institution, it is easy to forget that the Court is comprised of nine justices, each of whom is constrained individually by the need to secure the agreement of at least four colleagues in order to render legally efficacious constitutional rulings. ${ }^{224}$ Judges of courts of appeals are similarly constrained by the need to muster majority support for their conclusions. Unlike Supreme Court justices, lower court judges are of course further constrained by the Supreme Court's power to reverse their decisions. ${ }^{225}$

the previous prevailing constitutional assumptions).

221. Whittington, supra note 58, at 73.

222. Thomas M. Keck, The Most Activist Supreme Court in History: The Road to Modern Judicial Conservatism 277 (2004).

223. Adrian Vermeule, The Judiciary Is a They, Not an It: Interpretive Theory and the Fallacy of Division, 14 J. Contemp. Legal Issues 549 (2005) (echoing Kenneth A. Schepsle, Congress Is a “They," Not an "It”: Legislative Intent as an Oxymoron, 12 InT'L REV. L. \& ECON. 239 (1992)).

224. For an interesting discussion of the related issue of how the breadth and significance of judicial opinions tends to be influenced by the ideological cohesion of the justices forming the majority, see Nancy Staudt, Barry Friedman, \& Lee Epstein, On the Role of Ideological Homogeneity in Generating Consequential Constitutional Decisions, 10 U. PA. J. Const. L. 361 (2008).

225. Scholars have debated whether lower courts are bound to decide a case as they think that higher courts would on appeal, or whether they may offer independent judgments without attempting to emulate a superior court. Compare Michael C. Dorf, Prediction and the Rule of Law, 42 UCLA L. REv. 651, 655 (1995) (arguing that judges "generally ought not attempt to predict how other judges would rule" unless there are "special circumstances in which prediction is consistent with the rule of law”), with Evan H. Caminker, Precedent and Prediction: The Forward-Looking Aspects of Inferior Court Decisionmaking, 73 TEx. L. REv. 1, 6 (1994) (suggesting that lower courts should attempt to predict and emulate the decisions of higher courts in cases in which the "inferior court confronts strongly probative predictive data concerning its superior court's likely future ruling”), and Earl M. Maltz, The Concept of the Doctrine of the Court in Constitutional Law, 16 GA. L. REV. 357, 399 (1982) (arguing that greater uniformity will be achieved if lower courts attempt to imitate the Supreme Court). 
As I have noted, nonjudicial officials can defy or refuse to implement judicial decisions. Indeed, they have sometimes done so. ${ }^{226}$ The courts, however, are virtually never constrained by the need to earn the formal approval or acquiescence of officials in another branch in order to act with the authority of law. The reason, I would speculate, is that the Constitution is written, and surrounding norms and expectations have developed, on the hypothesis that the judiciary is the least dangerous branch. ${ }^{227}$ If the judiciary is assumed to be relatively impotent to inflict affirmative damage, and if the other branches are more threatening, it may be more desirable to preserve an efficacious checking power for the judiciary than to establish concurrent agreement or acquiescence requirements as formal checks against judicial action.

Having said this, I hasten to add that there may be circumstances under which the exercise of a judicial negative does indeed do affirmative harm-for example, if the Court unwisely invalidates legislation that would further important public interests or protect moral rights. ${ }^{228}$ Perceptions that the Court has done so partly explain some of the instances in which "reconstructive" presidents-including Abraham Lincoln and Franklin Roosevelt-have mounted successful attacks on previously prevailing visions of appropriate judicial authority under the Constitution. $^{229}$

\section{Sanctions}

The Constitution insulates the Supreme Court, as it does all federal judges, against certain kinds of sanctions. The justices cannot be removed from office during good behavior, nor can Congress reduce their salaries. ${ }^{230}$ All judges, justices included, also enjoy immunity from suits for civil damages based on their official acts. ${ }^{231}$

Despite these safeguards of judicial independence, the Constitution provides for some sanctions against Supreme Court justices. Most formally and conspicuously, justices can be impeached and removed from office. ${ }^{232}$ They are

226. See supra notes 194-203 and accompanying text.

227. See The Federalist No. 78 (Alexander Hamilton) (Clinton Rossiter ed., 1961).

228. See Fallon, supra note 103, at 1711 (noting the risk "that judicial review could sometimes frustrate legislative efforts to protect fundamental rights").

229. See generally Whittington, supra note 58, at 28-81 (discussing presidential challenges to judicial authority and successful efforts to reconstruct prevailing judicial regimes).

230. U.S. Const. art. III, § 1 .

231. See Stump v. Sparkman, 435 U.S. 349, 356 (1978) (reiterating the well-established doctrine of judicial immunity, under which a judge is absolutely immune from suit so long as he had jurisdiction over the subject matter of the challenged action and was performing a judicial act); see also Bradley v. Fisher, 80 U.S. 335, 347 (1871) (“[I]t is a general principle of the highest importance to the proper administration of justice that a judicial officer, in exercising the authority vested in him, shall be free to act upon his own convictions, without apprehension of personal consequences to himself.").

232. U.S. Const. art. II, § 4; see also The Federalist No. 8I (Alexander Hamilton) 
also subject to the criminal law, including its prohibitions against bribery and extortion.

Less formally, justices confront the possibility of sanctioning by their colleagues. If the justices thought one of their number to be reckless or cavalier in her constitutional judgments, they could deprive the wayward colleague of the privilege of speaking authoritatively for the Court simply by refusing to join her opinions. Or they could vote to rehear any case in which that colleague cast the decisive vote-as apparently happened with the aged William O. Douglas. $^{233}$ The justices' capacity to write opinions exposing their colleagues' constitutionally faithless reasoning (if such were ever to occur), and thus to hold up offenders to contempt or ridicule, may also qualify as a constitutionally authorized, albeit informal, sanction. $^{234}$

Beyond the sanctions available against Supreme Court justices, the Constitution provides mechanisms for the imposition of institutional sanctions, directed not against individual justices but the Court as a whole. The Constitution permits Congress to withdraw at least some cases from the Court's jurisdiction. ${ }^{235}$ If so minded, Congress and the president could also "pack" the Court and thereby not only reduce the power of incumbent justices, but also diminish the Court's prestige. ${ }^{236}$

Lower federal court judges are vulnerable to virtually the same sanctions as Supreme Court justices, but with one conspicuous addition. Unlike the justices, lower court judges are subject to being reversed, and potentially to being upbraided, on appeal. ${ }^{237}$

(Clinton Rossiter ed., 1961), at 453 ("There never can be danger that the judges, by a series of deliberate usurpations on the authority of the legislature, would hazard the united resentment of the body intrusted with it, while this body was possessed of the means of punishing their presumption, by degrading them from their stations.").

233. See Edward lazarus, Closed Chambers: The First Eyewitness Account of THE EPIC Struggles Inside the SuPReme Court 113 (1998).

234. For this reason, some scholars have urged reform to the random selection of panels in the courts of appeals to ensure that no more than two judges on each panel are from the same political party. The minority member of each panel could then "blow the whistle on the majority's unprincipled manipulation of doctrine (thereby enhancing exposure and the risk of a higher court reversal or perhaps damage to reputation of the panel majority).” Emerson H. Tiller \& Frank B. Cross, A Modest Proposal for Improving American Justice, 99 Colum. L. Rev. 215, 229 (1999).

235. See supra note 187 and accompanying text.

236. Over the course of American history, the number of seats on the Supreme Court has been as low as six and as high as ten. See FAllon ET AL., supra note 175, at 35 \& n.43. The most notorious effort to pack the Court was Franklin Roosevelt's ultimately unsuccessful threat to increase the size of the Court to avoid invalidation of New Deal legislation. See LeuchtenburG, supra note 111, at 84-85, 96-97, 112-21, 142-43, 216-20; Rafael Gely \& Pablo T. Spiller, The Political Economy of Supreme Court Constitutional Decisions: The Case of Roosevelt's CourtPacking Plan, 12 InT'L Rev. L. \& Econ. 45 (1992).

237. See Posner, supra note 9, at 141 (treating the prospect of reversal as an "external constraint" on judges because reversal "can imply criticism rather than merely disagreement, and no one likes a public rebuke"). 
Insofar as threats of sanctions function as a constraint on judicial action, their directive force could sometimes create a tension with applicable normative constraints. ${ }^{238}$ This prospect appears most visibly in the case of state judges, who may incur electoral or other political sanctions if their decisions displease a majority of voters. ${ }^{239}$ But it is at least imaginable that an irate or partisan Congress might sanction federal judges by impeaching them and removing them from office for rendering unpopular but legally correct decisions. $^{240}$

This possibility - which exemplifies the age-old dilemma of who should guard the guardians-is almost surely an unhappy one. But the threat has seldom if ever come to fruition. There are at least three lessons to be drawn.

First, nonjudicial actors within the American political system, including the public, have largely internalized a norm against attempts to interfere with the exercise of independent judgment by the federal judiciary, and especially the Supreme Court. Early in American constitutional history, the Jeffersonian Republicans threatened to impeach judges as an instrument of ideological discipline, but the effort foundered before it gained momentum. ${ }^{241}$ More than a century later, when Franklin Roosevelt sought authority to "pack” a Supreme Court that had appeared poised to scuttle hugely popular New Deal policies, Congress and public opinion rallied against the president. ${ }^{242}$ Similarly, although members of Congress have recurrently introduced legislation that would curb the authority of the federal courts to rule on controversial issues, ${ }^{243}$ such proposals have generally collapsed in the face of protests that they would violate the Constitution's spirit if not its letter. ${ }^{244}$

238. See id. at 274.

239. See supra note 114 and accompanying text.

240. Although in principle, judges and justices could be impeached only for committing "high Crimes and Misdemeanors,” U.S. Const. art. II, § 4, whether a judge has been properly impeached is apparently a "political question" that is not judicially reviewable. See Nixon v. United States, 506 U.S. 224, 226 (1993). Even recently, some members of Congress have threatened to impeach federal judges who render unpopular decisions. See Richard K. Neumann, Jr., The Revival of Impeachment as a Partisan Political Weapon, 34 Hastings ConsT. L.Q. 161, 163 (2007) (citing as one example the controversy surrounding Terri Schiavo's feeding tube and threats of impeachment made by some legislators when judges refused to reinsert the tube).

241. See Ackerman, supra note 195; Richard E. Ellis, The JefFersonian Crisis: Courts And Politics IN the Young Republic 69-82, 91-107 (1971) (describing the circumstances under which Jeffersonian Republicans in fact began impeachment proceedings against Federalist judges).

242. See LEUCHTENBURG, supra note 111, at 92-93, 95, 152-54.

243. See, e.g., Laurence H. Tribe, Jurisdictional Gerrymandering: Zoning Disfavored Rights out of the Federal Courts, 16 HARv. C.R.-C.L. L. REv. 129, 129 \& n.1 (1981) (describing the "barrage of proposals to curtail the jurisdiction of the federal courts" on issues ranging from abortion to busing to prayer in public schools).

244. See, e.g., Helen Norton, Reshaping Federal Jurisdiction: Congress's Latest Challenge to Judicial Review, 41 WaKe Forest L. Rev. 1003, 1003-04, 1010, 1028-32 (2006) (noting that the Senate never voted on bills that would have eliminated federal jurisdiction over First Amendment challenges to recitation of the Pledge of Allegiance or over any question involving 
Second, as I have noted already, other powerful political actors have good reasons to wish to maintain a relatively powerful, relatively independent judiciary. ${ }^{245}$ Granted, "reconstructive" presidents have sometimes sought to challenge the prevailing ideologically inflected assumptions through which the Constitution has predominantly come to be viewed. But even reconstructive presidents and their normal allies have either had normative compunctions about subjecting the Supreme Court to significant sanctions or have encountered external resistance when they attempted to do so.

Third, saying that the sanctioning of federal judges and especially the Supreme Court has occurred infrequently is different from saying that the prospect of sanctions has had no effect. As I have noted, judicial decisionmaking in the United States has long exhibited a streak of prudentialism, through which the Court has avoided not only particular decisions that might provoke defiance, but also broader patterns of rulings that could arouse political majorities to impose sanctions. ${ }^{246}$ Although I would stop considerably short of Judge Richard Posner's conclusion that "[c]onstitutional law is a function . . . of ideology” checked principally if not exclusively by the justices' “awareness, conscious or unconscious, that they cannot go 'too far' without inviting reprisals by the other branches of government spurred on by an indignant public, "247 it seems only commonsensical to assume that sanctions or other external constraints have some effect.

IV

CONSTITUTIONAL CONSTRAINTS ON NONJUDICIAL OFFICIALS

In formal terms, nonjudicial officials-including presidents and members of Congress-are subject to the same varieties of internal and external constraint as Supreme Court justices. In substantive respects, the operative constraints differ markedly.

\section{A. The Internal Point of View: Normative Constraints}

\section{Direct Normative Constraints}

Although we may tend to equate the Constitution with the judicially enforced Constitution, to do so is a mistake. Nonjudicial officials are subject to a variety of direct normative constraints: in numerous contexts they are obliged to do what the Constitution directly and substantively requires of them, wholly independently of anything courts might say.

246. See Fallon, supra note 195, at 16-20, 27-33.

247. See Posner, supra note 9, at 375. 
To begin with, it is widely presumed that members of Congress are normatively obliged not to vote for, ${ }^{248}$ and that presidents are similarly normatively constrained not to sign into law, ${ }^{249}$ legislation that they believe to be unconstitutional, even if they think a court might uphold it. Among other things, as Larry Sager has long maintained, some judicial doctrines may underenforce the constitutional guarantees on which they rest, perhaps most frequently because of practical and prudential considerations. ${ }^{250}$ The bite of the underenforcement thesis resides in the claim that even when constitutional guarantees are judicially underenforced, their normative content should bind nonjudicial officials. ${ }^{251}$

Beyond appraising the constitutionality of legislation, executive officials and legislators must determine how the Constitution bears on some of their most basic obligations of office. Among the cases in which legislators and executive officials must construe the Constitution are those presenting political questions. ${ }^{252}$ Beyond the formally denominated political question doctrine, members of Congress must decide how, if at all, the Constitution speaks to issues involving the proper use of their powers to trade votes, demand special favors for constituents as a condition of support for legislation, engage in filibusters, and withhold their consent from presidential nominations. Similarly, presidents must decide what count as constitutionally appropriate criteria on which to nominate candidates to constitutional office, including the federal judiciary. Presidents also have broad discretion to define their obligation to "take Care that the Laws be faithfully executed.,253

On matters of greater topical interest, presidents and those advising them must also make numerous determinations of constitutional legality concerning

248. See, e.g., Boumediene v. Bush, 128 S. Ct. 2229, 2243 (2008) (“The usual presumption is that Members of Congress, in accord with their oath of office, considered the constitutional issue and determined the amended statute to be a lawful one....”); id. at 2296 (Scalia, J., dissenting) ("We have frequently stated that we owe great deference to Congress's view that a law it has passed is constitutional.”); U.S. Dep’t of Lab. v. Triplett, 494 U.S. 715, 721 (1990).

249. Saikrishna Prakash, Why the President Must Veto Unconstitutional Bills, 16 WM. \& Mary Bill RTs. J. 81, 82 (2007).

250. See Sager, supra note 176, at 1212-13; see also SAGER, supra note 178, at 6-7.

251. See Sager, supra note 176, at 1263-64. I have registered a partial disagreement on the ground that if, as Sager argues, "institutional factors" can sometimes excuse the courts from enforcing constitutional norms to their full conceptual limits, other "institutional" considerations might similarly justify Congress and the executive in allowing "underenforcement" to occur. See Richard H. Fallon, Jr., Judicially Manageable Standards and Constitutional Meaning, 119 Harv. L. REv. 1275, 1323-27 (2006).

252. On the political question doctrine, see generally FALLON ET AL., supra note 175, at 244-67.

253. U.S. Const. art. II, § 3; see, e.g., Heckler v. Chaney, 470 U.S. 821, 832 (1985) (reiterating that the decision of a prosecutor to indict "has long been regarded as the special province of the Executive Branch,” free from judicial control); Steven G. Calabresi \& Saikrishna B. Prakash, The President's Power to Execute the Laws, 104 Yale L.J. 541, 582-84 (1994) (reading the Take Care Clause to bolster the unitary executive argument that "the President possesses unique powers with respect to the execution of the law"). 
matters - some but not all related to national security - that are unlikely ever to come before a court and on which there are no close judicial precedents. As I have noted, the historical record suggests that some officials take their constitutional obligations very seriously in such cases. ${ }^{254}$ It also bears noting that the Constitution's import in many national security cases has occasioned dispute and, significantly, that many critics accuse executive officials of having breached important normative obligations. ${ }^{255}$

In characterizing nonjudicial officials who regard the Constitution from an internal point of view as subject to direct normative constraints, I make no specific claim about those constraints' substantive content or their motivational efficacy. Bypassing those issues, I offer three further comments.

First, as my reference to national security matters may have suggested, executive officials - like Supreme Court justices — can reasonably disagree, and sometimes be mistaken, about what their constitutional powers and obligations are. $^{256}$ Moreover, in determining what the Constitution permits or requires, executive officials — again like Supreme Court justices-sometimes may need to make contestable judgments of what would be legally "best." From the absence of agreement among executive officials, one should not infer the absence of normative constraint, either in the objective or the subjective sense.

Second, the institutional environment in which officials function may influence their psychological apprehensions of the normative constraints to which they are subject. ${ }^{257}$ For example, insofar as ideologically like-minded people deliberate in private about what the Constitution requires or permits, recent psychological studies suggest that their interactions may tend to push them to more extreme positions than most or even any would have held initially. $^{258}$ To say that officials experience normative constraints and obligations is thus not to say that their constitutional judgments are wholly disinterested, rather than partly ideologically driven. This is one reason to believe that some, if not all, normative constraints on nonjudicial officials should be enforced by external constraints.

Third, I believe that elected officials, especially the president, would view themselves as normatively empowered and constrained to treat ultra vires judicial rulings—-such as orders to the Federal Reserve to raise interest rates or

254. See supra notes 35-37 and accompanying text.

255. For opinionated surveys of the leading debates, see, for example, GoLDSMITH, supra note 5; MAYER, supra note 5; Yoo, supra note 5.

256. See, e.g., GolDSMith, supra note 5, at 129 (observing that he "grudgingly admired" the "perverse integrity" of an administration official who believed in nearly unlimited executive power "even when I thought his judgments were crazy").

257. See, e.g., Martha Minow, Living Up to Rules: Holding Soldiers Responsible for Abusive Conduct and the Dilemma of the Superior Orders Defence, 52 McGill L.J. 1, 33-35 (2007) (tracing psychological factors that tend to promote conformity of behavior to group norms and expectations).

258. See, e.g., Cass R. Sunstein, Deliberative Trouble? Why Groups Go to Extremes, 110 YALE L.J. 71, 118-19 (2000). 
to military officials to pursue different tactics in battle-as lacking the authority of law. ${ }^{259}$ Just as some normative constraints on nonjudicial officials are and should be buttressed by external constraints, the Supreme Court's sense of normative constraint does not and should not furnish the only constitutional safeguard against government by judiciary.

\section{Mediated Normative Constraints}

Most officials understand themselves as normatively constrained by judicial interpretations of the Constitution very much, if not all, of the time, even when they disagree vehemently with court rulings. Questions involving nonjudicial officials' legal and moral obligations to act in accordance with judicial decisions are surprisingly diverse. Some are very difficult. ${ }^{260}$ Nearly everyone agrees that officials should regard themselves as normatively bound by judicial determinations in cases to which they are parties, at least outside the scope of patently ultra vires rulings. ${ }^{261}$ By contrast, it is commonly believed that presidents and members of Congress are respectively entitled to veto or to vote against legislation that they think unconstitutional even if the courts would disagree. $^{262}$

Perhaps the most actively debated question involves the extent to which a judicial ruling in one case should bind officials who were not parties to the action. The leading case is Cooper v. Aaron, ${ }^{263}$ in which a unanimous Supreme Court asserted a general obligation of government officials - whether or not they were named parties to lawsuits-to implement constitutional principles as the Court articulates them. ${ }^{264}$

Although there is much to be said both for and against the position that the Court staked out in Cooper, ${ }^{265}$ the principal point that I want to make, as

259. See Baude, supra note 191, at 1862 (arguing that officials have no obligation to obey judicial orders that exceed the scope of judicial jurisdiction).

260. For leading discussions on this topic, see sources cited supra note 97.

261. See Fallon, supra note 107 , at 1 \& n.1. The one prominent dissenter from the consensus view is Michael Paulsen, who argues instead that the president may refuse to follow the Supreme Court's interpretations of the law, and that "he may exercise such powers of legal review even in the specific case where courts have ruled against his position; that is, he may refuse to execute (or, where directed specifically to him, refuse to obey) judicial decrees that he concludes are contrary to law.” Paulsen, supra note 97, at 222.

262. See, e.g., Gary Lawson \& Christopher D. Moore, The Executive Power of Constitutional Interpretation, 81 Iowa L. REv. 1267, 1309-10 (1996); Rex E. Lee, The Provinces of Constitutional Interpretation, 61 TuL. L. REv. 1009, 1012 (1987).

263. 358 U.S. 1, 4 (1958).

264. Id. at 18; see also United States v. Nixon, 418 U.S. 683, 704 (1974).

265. At least two rationales might support the Cooper approach. According to Professors Alexander and Schauer, a fundamental goal of the Constitution is to achieve authoritative resolution of issues about which reasonable people can differ; and authoritative resolution is possible, they say, only if other officials swiftly accept Supreme Court decisions as binding. See Alexander \& Schauer, Extrajudicial Interpretation, supra note 97, at 1371-81. Another supporting argument would attempt to build on general jurisprudential claims, most prominently 
throughout this article, is more analytical than normative: the question of an official's normative obligation to obey a judicial decision must always and inevitably be refracted through that official's mind and conscience. Although it is certainly possible to take a "Catholic" position with respect to matters of constitutional obligation, believing oneself bound by what others have determined, even the most deferential Catholic must decide for herself that she ought to be a Catholic-or an adherent to Cooper v. Aaron-rather than an interpretive Protestant. ${ }^{266}$ Today, most officials and citizens appear to regard themselves as normatively bound to obey and enforce broad judicial pronouncements rendered in cases to which they were not parties. But we can never know for certain that a Protestant revolution is not in the offing, or would not be provoked by some imaginable courses of decision making by the Supreme Court. ${ }^{267}$ As I suggested earlier, the justices may well bear this consideration in mind when deciding controversial cases.

\section{Constitutionally Authorized Normative Constraints}

Constitutionally valid federal legislation subjects the president and the executive branch to a myriad of indirect, constitutionally authorized constraints. Many federal statutes either mandate or forbid executive action. Even when legislation applies in terms only to private conduct, the president has a constitutional obligation to take care that the laws are faithfully executed. $^{268}$

offered by Joseph Raz, that root legitimate legal authority in epistemic competence. See Joseph Raz, The Problem of Authority: Revisiting the Service Conception, 90 Minn. L. Rev. 1003 (2006); see also Joseph Raz, The Morality of Freedom (1986). According to Raz, morally conscientious citizens should accept the dictates of legal authorities when they have good reason to believe that the legal authorities can make better decisions than they could make themselves. See Raz, supra, at 1018-20. Similarly, a defense of Cooper might assert that courts, and especially the Supreme Court, have a special competence in constitutional interpretation. See, e.g., Alexander M. Bickel, The Least Dangerous Branch: The Supreme Court at the Bar of Politics 25 (1962) (defending judicial review on the premise that "courts have certain capacities for dealing with matters of principle that legislatures and executives do not possess"). If so, perhaps other officials should understand themselves as constitutionally obliged to accept the Court's pronouncements, due to the likelihood that the Court's determinations are correct.

In my judgment, neither of these arguments proves wholly convincing. As I have meant to emphasize, the Constitution is not just a document for judges; it could not function effectively if it were. To get disputed questions settled authoritatively is one reason to have a constitution, but not the only reason. Especially with respect to disputable matters, judicial decisions should not too quickly foreclose democratic debate. Recognition that some matters of constitutional interpretation are reasonably disputable also undermines arguments that rely on strong assumptions about the superior epistemic competence of courts. See Jeremy Waldron, The Core of the Case Against Judicial Review, 115 Yale L.J. 1346 (2006).

266. On the distinction between Catholic and Protestant approaches to constitutional interpretation, see supra notes 96-98 and accompanying text.

267. See, e.g., Whittington, supra note 58, at 27 ("We can easily imagine presidents dismissing the authority of the Court and ignoring its opinions .... We can easily imagine a Court reduced to political subservience ....”).

268. U.S. Const. art. II, § 3. 
Because Congress is the lawmaking branch, it may be subject to fewer indirect, constitutionally authorized constraints than either the president or the judiciary. But one can imagine members of Congress feeling indirectly normatively constrained by the constitutionally authorized actions of past Congresses, even if the pertinent normative obligations are not judicially enforceable. Examples might include normative obligations to fund payments of the national debt and to pay veterans' benefits. Although the doctrine of sovereign immunity would likely bar judicial enforcement of any promise by the government to pay money if the government chose to renounce its obligations, ${ }^{269}$ conscientious members of Congress well might view themselves as indirectly normatively constrained by the actions of predecessor Congresses. Treaties may also impose indirect normative constraints on presidents and Congress to take steps necessary to satisfy the nation's promises. ${ }^{270}$

\section{B. The External Point of View and External Constraints}

\section{Inefficacy or Nullity Under Applicable Rules of Recognition}

As I have noted, officials would never seriously contemplate many actions because they know that those actions would be null or inefficacious. If purported “official” actions were sufficiently clearly ultra vires, judicial rulings to that effect would not be necessary.

In other cases, officials must contemplate the possibility that actions that would not otherwise be obviously unconstitutional would be treated as null or inefficacious under past judicial decisions. For example, police officers know that evidence procured in contravention of judicial interpretations of the Fourth Amendment will prove legally ineffective for its intended purpose, ${ }^{271}$ as will confessions elicited without Miranda warnings. ${ }^{272}$ Some actions might also lead to sanctions - a further external constraint that I discuss below.

Matters are too complex, however, to permit simple summary. Some official actions that deviate from judicial pronouncements do not prove inefficacious. Officials in some communities defied the ruling of Brown $v$.

269. See FAllon ET AL., supra note 175, at 938-72 (discussing federal sovereign immunity).

270. Although it appears settled that treaties calling for the expenditure of funds require implementing legislation, see Edwards v. Carter, 580 F.2d 1055, 1058 (D.C. Cir. 1978), the question whether Congress has a duty to appropriate money is distinct, and was actually a subject of congressional debate in connection with the 1794 Jay Treaty with Great Britain. See DAvid P. Currie, The Constitution in Congress: The Federalist Period, i789-I80i, at 211-17 (1997).

271. See Mapp v. Ohio, 367 U.S. 643, 660 (1961) (holding that the exclusionary rule, which prevents the use of unconstitutionally seized evidence at trial, is enforceable against the states through the Due Process Clause of the Fourteenth Amendment).

272. See Miranda v. Arizona, 384 U.S. 436, 476-77 (1966) (providing that statements given absent Miranda warnings will be inadmissible against a criminal defendant). 
Board of Education ${ }^{273}$ for a decade or more. ${ }^{274}$ Even today, public school officials in some parts of the country apparently assemble their students to pray, $^{275}$ despite Supreme Court decisions holding such conduct unconstitutional. ${ }^{276}$ Thus, the extent to which executive and legislative actions that defy judicial pronouncements will be regarded as null or otherwise prove ineffectual is as much an empirical-sociological question as it is a legal one. ${ }^{277}$

\section{Concurrent Agreement or Acquiescence Requirements}

An important subcategory of nullity or inefficacy constraints arises from concurrent agreement requirements: nonjudicial officials are frequently constrained from acting efficaciously unless they can procure the concurrent agreement or acquiescence of other officials. Indeed, as I emphasized above, judicial review of legislation embodies a kind of concurrent agreement or acquiescence requirement.

The demand that Congress and the president receive the concurrent agreement or acquiescence of the courts in order to act with legal authority, whereas the Supreme Court seldom needs the concurrent agreement of another branch in order to make legally binding rulings, reflects a notable asymmetry in the distribution of constitutional powers. The best explanation is not that the Constitution encourages government by judiciary. It is, rather, that the Constitution assumes that executive and legislative power, if not subject to concurrent agreement and acquiescence requirements, would be more dangerous than assertions of legitimate judicial power. By design, the Constitution makes governmental action-and especially lawmakingdifficult, and establishes inaction as the preferred default position. ${ }^{278}$ As I have noted before, judicial power is typically power to nullify or veto, not to issue

273. 347 U.S. 483 (1954).

274. See Klarman, supra note 146, at 397-421.

275. See, e.g., Ashutosh Bhagwat, Cooper v. Aaron and the Faces of Federalism, 52 ST. Louis U. L.J. 1087, 1109 (2008) (citing evidence of "widespread defiance" of the Supreme Court's school prayer decisions).

276. Abington Sch. Dist. v. Schempp, 374 U.S. 203, 225-27 (1963) (holding unconstitutional mandatory Bible reading in public schools); Engel v. Vitale, 370 U.S. 421, 436 (1962) (holding that it violates the Establishment Clause for school officials to initiate school prayer).

277. See generally Gerald N. Rosenberg, The Hollow Hope: Can Courts Bring About Social Change? (1991) (arguing that a number of celebrated Supreme Court decisions proved largely ineffectual as engines of social change); Louis Fisher, Constitutional Dialogues: Interpretation as Political Process 221-29 (1988) (identifying factors that can lead to noncompliance with Court decisions).

278. See, e.g., John F. Manning, Textualism as a Nondelegation Doctrine, 97 Colum. L. REv. 673, 707-10 (1997) (describing how protections built into the lawmaking process "raise the decision costs associated with lawmaking, safeguarding liberty through a deliberate sacrifice of governmental efficiency" because the Framers "saw the risks of ill-advised governmental action as far greater than the risks of inaction"); see also The Federalist No. 73 (Alexander Hamilton) (Clinton Rossiter ed., 1961), at 442 ("The injury which may possibly be done by defeating a few good laws, will be amply compensated by the advantage of preventing a number of bad ones.”). 
affirmative mandates.

To be sure, conspicuous exceptions to this generalization exist, especially with the advent of "public rights" litigation in which single lawsuits determine the rights of many claimants and sometimes produce decrees ordering large changes in governmental operations. ${ }^{279}$ Brown v. Board of Education ${ }^{280}$ and the one-person, one-vote cases $^{281}$ provide telling examples. Nevertheless, judicial decisions that broadly alter settled understandings of rights and responsibilities remain more the exception than the norm. The recurring impulse to distinguish negative from positive rights, ${ }^{282}$ and to restrict the courts to enforcing the latter, ${ }^{283}$ may testify to the endurance of the intuition that courts need not be subject to the same kinds of concurrent agreement and acquiescence requirements as the political branches because judicial power is less sweeping and affirmative, and thus less dangerous, than executive and legislative power.

\section{Sanctions}

Nonjudicial officials, especially in the executive branch, are commonly subject to a range of potential sanctions that includes, but is not limited to, criminal punishments, civil damages, and injunctive remedies. ${ }^{284}$ The legislative branch possesses authority to investigate and expose alleged misconduct by executive officials, ${ }^{285}$ with the resulting loss of reputation

279. See, e.g., Abram Chayes, The Role of the Judge in Public Law Litigation, 89 HARv. L. Rev. 1281, 1289-92, 1294-96 (1976) (distinguishing public law or public rights litigation from traditional litigation); William A. Fletcher, The Discretionary Constitution: Institutional Remedies and Judicial Legitimacy, 91 YALE L.J. 635, 638-41 (1982).

280. 347 U.S. 483 (1954).

281. See, e.g., Reynolds v. Sims, 377 U.S. 573, 624-25 (1964).

282. See, e.g., Susan Bandes, The Negative Constitution: A Critique, $88 \mathrm{Mich}$. L. Rev. 2271 (1990); David P. Currie, Positive and Negative Constitutional Rights, 53 U. CHI. L. Rev. 864, 864-67 (1986).

283. See, e.g., Robert H. Bork, Commentary: The Impossibility of Finding Welfare Rights in the Constitution, 1979 WASH. U. L.Q. 695, 696 (urging against recognition or judicial enforcement of welfare rights under the Constitution because "the end result would be to convert our government from one by representative assembly to one by judiciary"); Cass R. Sunstein, Against Positive Rights, in Western Rights? Post-Communist Application 225-32 (András Sajó ed., 1996) (claiming that it is "a large mistake, possibly a disaster" to include positive rights in constitutions in countries transitioning from communism to a market economy). But see Mark Tushnet, Social Welfare Rights and the Forms of Judicial Review, 82 Tex. L. Rev. 1895, 1919 (2004) (arguing that "[t]he experience of constitutional courts around the world suggests that scholars of U.S. constitutional law would do well to rethink the conventional wisdom about the inclusion of social welfare rights in judicially enforceable constitutions").

284. See generally FALLON ET AL., supra note 175, at 938-1141 (surveying jurisdictional and related doctrines applicable to legal actions against the government and government officials); Peter H. Schuck, Suing Government: Citizen Remedies for Official Wrongs 29-53 (1983). For a historical discussion of evolving patterns of civil remedies against government officials and the contours of official immunity, see Ann Woolhandler, Patterns of Official Immunity and Accountability, 37 CASE W. Res. L. Rev. 396, 397-400 (1987).

285. Congress also wields the power of impeachment. U.S. Const. art. I, § 2, cl. 5; id. art. I, § 3, cl. 6 . 
potentially rising to the level of an informal sanction. In addition, both the voters and higher-level executive officials can often, although not always, impose the informal but de facto sanction of removal from or non-retention in office.

Although not all sanctions against the executive branch are judicial sanctions, nearly everyone seems to assume that judicial sanctions are vital to enforcing executive officials’ mediated normative obligations to obey judicial interpretations of constitutional norms. Many observers thus regard suits for damages and the exclusionary rule (which might plausibly be classified as a sanction, rather than a concurrent agreement requirement, in cases in which the underlying norm is well established) as necessary tools for achieving police compliance with constitutional norms bearing on criminal investigations. ${ }^{286}$ In a historical study, Michael Klarman identifies the general absence of sanctions against law enforcement officials and jury commissioners as a central reason that Supreme Court decisions establishing rights of racial equality went widely unenforced in the South before the 1960s. ${ }^{287}$

In order for an action to incur sanctions, its occurrence must of course be known. From this commonplace observation flows an implication of large importance: officials of the executive branch are likely to be less externally constrained by the threat of sanctions when they are able to act in secret than when their conduct is known or likely to become known to the broader public.

Scandals involving abuse of prisoners in the so-called "War on Terror" are revealing in this respect: officials who have wanted to pursue interrogational and other information-gathering tactics of doubtful legality have understood that their capacity to do so depends on their ability to keep their actions secret, often even from others within the executive branch. ${ }^{288}$ I use the term “doubtful legality” advisedly, for it appears that many high-level officials have sincerely believed that the Constitution vests the president with national security powers that trump otherwise applicable legal principles. ${ }^{289}$ In their view, any sanctions applied against officials who do what they reasonably think needs to be done to protect national security would reflect constitutional misjudgments by the sanctioning agents. ${ }^{290}$

286. See, e.g., Sherry F. Colb, Innocence, Privacy, and Targeting in Fourth Amendment Jurisprudence, 96 Colum. L. Rev. 1456, 1521 (1996); Myriam E. Gilles, In Defense of Making Government Pay: The Deterrent Effect of Constitutional Tort Remedies, 35 GA. L. Rev. 845, 855 (2001).

287. See Michael J. Klarman, Brown v. Board of Education and the Civil Rights MOVEMENT 223-24 (2007).

288. See MAYER, supra note 5; GoldSMITH, supra note 5.

289. See MAYER, supra note 5, at 48-71; GolDSMITH, supra note 5, at 124-29, 167-72; Yoo, supra note 5, at 102-04, 113-14, 168-87.

290. The link between public exposure of and external constitutional constraints on executive behavior illustrates the function of the press-typically abetted by informants or leakers-as a metaphorical "fourth branch" of government, crucial to the constitutional scheme of checks and balances. The press's sometimes peculiar status also gives rise to questions, which I 
Members of the legislative branch are subject to fewer judicial sanctions than are members of the executive. Legislative officials enjoy absolute immunity from damages liability for their legislative acts. ${ }^{291}$ Injunctions against legislative action are of uncertain constitutional validity. ${ }^{292}$ The best explanation for the disparity in the availability of judicial sanctions probably involves the capacity of executive officials to practice direct coercionsomething that legislators ordinarily cannot do.

Comparison of executive officials with judges might appear to cast doubt on this suggestion; judges enjoy absolute immunity from damages liability for actions-including coercive actions - taken in a judicial capacity. ${ }^{293}$ If one asks why damages remedies are widely assumed vital in ensuring executive, but not judicial, adherence to law, ${ }^{294}$ the answer may be that the legal process affords safeguards against abuse that are frequently lacking in the case of executive action. Among other considerations, judicial action is almost always public, not secret. Consequently, it may not occasion the special need for deterrence that exists in contexts in which executive officials hope to hide their coercive actions but know that they may not succeed in doing so. Another, possibly related, reason might be that the judges who have crafted immunity doctrines regard their fellow members of the judicial branch as more likely than executive officials to obey the law in the absence of threats of sanctions. ${ }^{295}$

cannot explore here, about the normative and external constraints to which the press is and ought to be subject. For a critical discussion of recent conduct by the press in exposing operations that compromised intelligence-gathering activities, see Jack Goldsmith, Secrecy and Safety, 239 New REPUBLIC 31 (2008).

291. See Gravel v. United States, 408 U.S. 606, 623-25 (1972) (interpreting the Speech and Debate Clause, U.S. Const. art. I, $\S 6$, as shielding all acts that are "an integral part of the deliberative and communicative processes by which Members participate in committee and House proceedings with respect to the consideration and passage or rejection of proposed legislation or with respect to other matters which the Constitution places within the jurisdiction of either House”); see also Tenney v. Brandhove, 341 U.S. 367, 379 (1951) (extending legislative immunity to state legislators).

292. For discussion of the leading cases and some of the remaining uncertainties, see FALlON ET AL., supra note 175, at 1135-36.

293. See, e.g., Stump v. Sparkman, 435 U.S. 349, 362-64 (1978).

294. The classic explanation offered by the Supreme Court is that "it is a general principle of the highest importance to the proper administration of justice that a judicial officer, in exercising the authority vested in him, shall be free to act upon his own convictions, without apprehension of personal consequences to himself.” Bradley v. Fisher, 80 U.S. 335, 347 (1871); see also ScHucK, supra note 284, at 90 (summarizing the Court's justifications for absolute judicial immunity).

295. Cf. Butz v. Economou, 438 U.S. 478, 528 n.* (1978) (Rehnquist, J., concurring in part and dissenting in part) ("If one were to hazard an informed guess as to why such a distinction in treatment between judges and prosecutors, on the one hand, and other public officials on the other, obtains, mine would be that those who decide the common law know through personal experience the sort of pressures that might exist for such decision makers in the absence of absolute immunity, but may not know or may have forgotten that similar pressures exist in the case of nonjudicial public officials to whom difficult decisions are committed. But the cynical among us might not unreasonably feel that this is simply another unfortunate example of judges treating those who are not part of the judicial machinery as 'lesser breeds without the law.”). 
Without going into detail, I offer just one further comment: however vital sanctions may be in constraining official action, especially by the executive branch, there can be no guarantee that sanctioning authorities will administer sanctions appropriately - a point that I have made previously, but one worth repeating. In a vivid illustration, some official courses of action or inaction might actually trigger rival sanctions. For example, even after the time finally came when southern officials might have incurred sanctions from the courts for not implementing the mandate of Brown v. Board of Education, those officials might nevertheless have provoked sanctions from the voters if they had acquiesced without resistance. ${ }^{296}$ Or an executive branch official might be sanctioned by superiors for what the superiors regard as dereliction of duty unless the lower-ranking official takes actions that courts would punish in a case before them. In an analogous if not identical situation, some officials of the Bush administration lost their jobs when they resisted assertions by other, higher-level officials that the executive branch was largely unconstrained by law in seeking to combat international terrorism. ${ }^{297}$

When elected officials would risk sanctions if they followed courses of action that they feel normatively constrained to pursue, it is tempting to conclude that normative constraints should always prevail. In considering the practical implications of this suggestion, however, one should recall that all purely normative constraints necessarily operate through each official's individual mind and conscience. Inevitably, some officials will acknowledge no mediated normative obligation to adhere to judicial decisions that they regard as erroneous. And of those who insist on interpreting the Constitution for themselves, some may have eccentric or even dangerously roguish understandings.

An alternative prescription would be that officials should always regard their mediated normative obligations arising from judicial interpretations of the Constitution as determining what they ought to do. ${ }^{298}$ Regardless of the wisdom of this suggestion, it seems plain that officials do not always follow it. Moreover, it might well be intolerable if judges and justices ceased to be constrained at all by the threat that some imaginable judicial decrees would be treated as nullities.

At the end of the day, perhaps no more can be said than this: sanctions are an important mechanism of constitutional enforcement; they are sometimes more and sometimes less effective; and they will occasionally be employed misguidedly. In all cases, however, sanctioning officials and institutions-as much as the targets of sanctions-function within a network of empowerments

296. See Klarman, supra note 146, at 398-99, 401, 405-21 (describing electoral disincentives for southern officials to desegregate until the courts made it clear that they had no alternative).

297. See MAYER, supra note 5, at 308.

298. See Alexander \& Schauer, Extrajudicial Interpretation, supra note 97. 
and constraints in which none is wholly unconstrained.

\section{CONCLUSION}

In this Article, I have sought first to unpack or make intelligible, and then to provide a framework for answering, the questions whether, how, and to what extent the Constitution constrains government officials. Answers must begin with the proposition that constitutional constraint and empowerment are two sides of the same coin. The Constitution constrains most fundamentally by constituting a matrix of institutions and offices in which the powers of any one are defined and limited by the understandings, expectations, and powers of others. To be a president or a Supreme Court justice is to have some lawful powers but not others. Constraint inheres not just in threats of sanctions, but also in the incapacity to act with recognized authority beyond the sphere of tenable claims of lawful power, and in norms that define official roles and obligations.

In considering the nature and extent of constitutional constraints on the Supreme Court, in particular, most of us tend to focus too readily on the domain in which the justices seem least constrained-in determining whether the actions of other institutions of government are constitutionally valid or not. In asking only whether and how the Supreme Court is constrained in adjudicating the constitutionality of abortion restrictions or affirmative action, for example, we risk misunderstanding not only how constrained the justices are from asserting power over other matters, but also how it is that the Constitution constrains the justices, as well as other officials, most fundamentally.

Within the network of roles and institutions that the Constitution constitutes, officials, including justices, are subject to constraints of two basic kinds. First, officials who accept the Constitution's authority-as most presumably do-will experience themselves as subject to normative constraints. They will regard the Constitution as providing them and others with reasons to take some actions and forego others. They will view deviations from constitutional norms as grounds for criticism and self-criticism. But not all of the normative constraints that the Constitution establishes are of the same type. Direct normative constraints, which reflect the Constitution's mandates under accepted rules of recognition, need to be distinguished from mediated normative constraints, which apply when the Constitution requires one institution or official to accept another institution's or official's interpretations as binding.

In one sense, normative constitutional constraint is a matter of law, independent of what any particular official believes the law to be. To be normatively constrained by the Constitution is simply to acknowledge a duty to do what the Constitution requires. As a practical matter, however, normative constraints are necessarily refracted through the minds of particular officials. In 
another sense, direct normative constraints are, thus, the perceptions of constitutional obligation experienced by particular officials even when they disagree with one another about what the Constitution requires and even when at least one must be in error. When the term "direct normative constraint" is used in this second sense, some justices or other officials may feel constrained to uphold a claim of constitutional right, while others feel constrained to reject it. Absence of agreement does not imply an absence of felt constitutional constraint - even if one believes that it would be preferable for the Constitution to constrain more determinately or unmistakably than it does.

The possibility of dispute about constitutional meaning, or about the constraints that the Constitution directly imposes, helps explain why mediated constitutional constraints play such an important role in our constitutional scheme. Under currently prevailing understandings, nonjudicial officials are frequently constrained not by the Constitution's substantive demands as they would correctly be understood, or as each official personally understands them, but by the interpretations propounded by the judicial branch. Within boundsbut only within bounds, as I have tried to show- - "the Constitution is what the judges say it is." 299

The second main variety of constitutional constraints, which I have called external constraints, arises not from officials' conscientious commitment to obeying the Constitution, but from social facts involving other officials' and the general public's understandings of the limits of lawful official conduct. Officials know that if they violate widely recognized boundaries on their authority, their assertions of power would prove inefficacious, and in some cases could incur sanctions. The prospect of inefficacy and the threat of sanctions function as significant external constraints on official action.

In maintaining that public officials can be motivated by both normative and external constraints, I have scrupulously tried not to claim a categorical priority for one or the other. Although I find it hard to believe that the Constitution could function effectively without inspiring a motivationally efficacious sense of obligation in at least some officials, neither could I imagine a workable legal regime without external constraints on official action. For the most part, moreover, observable patterns of official compliance with law tend to be equally consistent with the competing hypotheses that officials act from a sense of constitutional obligation and that they adapt their self-interested behavior to external constraints.

In a few cases, the normative and external constraints may diverge. For example, high-level officials in the executive branch could sanction subordinates for refusing to breach constitutional norms in attempting to eradicate national security threats, or the voters could sanction a state court judge for upholding unpopular but valid constitutional claims. For the most

299. See supra note 2 and accompanying text. 
part, however, external constraints tend to reinforce normative constraints on official action. And in a few instances, I have speculated, external constraints may actually help to shape prevailing understandings of what the Constitution normatively permits or requires. Similarly to the way in which "ought implies can" in the realm of morals, ${ }^{300}$ we may tend to assume in law that Supreme Court justices, in particular, have no constitutional obligation to attempt to do what-because of external constraints - they could not do efficaciously. For example, I would argue that under prevailing rules of recognition, the justices are not always duty-bound to enunciate constitutional principles that, in a particular historical epoch, would prove too publicly and politically unacceptable to be enforced effectively.

Among the external constraints that officials must observe in order to act efficaciously, concurrent agreement or acquiescence requirements possess an importance that bears separate mention. Members of Congress and often the executive branch, including the president, cannot act with the authority of law unless they can procure the concurrent agreement or acquiescence of other officials. Members of Congress cannot legislate without the concurrent agreement of a majority of their colleagues; the president often requires congressional authorization; and otherwise efficacious official acts will be viewed as null unless the courts concur in judging them constitutionally valid.

Because the courts, unlike Congress and the president, typically do not require the concurrence or acquiescence of other branches in order to act with legal authority, the judicial branch can appear to be peculiarly, even dangerously, unconstrained. But the suggestion that we have an unconstrained judiciary does not withstand analysis. Examined as a whole, the Constitution embodies a premise - whether correct or incorrect - that governmental action is presumptively more dangerous than governmental inaction and should, accordingly, be subject to more veto opportunities. Because the judiciary controls neither the sword nor the purse, its principal power is to nullify attempted action by officials of other branches, not to implement policy initiatives of its own. In this sense, the judiciary remains the least dangerous branch, even if its powers to constrain the other branches have increased dramatically over the arc of constitutional history. Those who view the modern judiciary as relatively unconstrained have misunderstood the ways in which the Constitution constrains most effectively and fundamentally.

300. Immanuel Kant, Critique of Judgment 345 n.48 (Werner S. Pluhar trans., 1987). 
